\title{
23. MIOCENE EVOLUTION OF CARBONATE SEDIMENTATION AT THE CEARA RISE: A MULTIVARIATE DATA/PROXY APPROACH ${ }^{1}$
}

\author{
T. A. King, ${ }^{2}$ W.G. Ellis, Jr., ${ }^{2,3}$ D.W. Murray, ${ }^{4}$ N.J. Shackleton,,${ }^{5}$ and S. Harris ${ }^{6}$
}

\begin{abstract}
Synthetic records of percent $\mathrm{CaCO}_{3}$, carbonate mass accumulation, and noncarbonate (terrigenous) mass accumulation are developed for late Neogene portions of Ceara Rise Sites 925-929. Shipboard measurements of natural gamma emissions and magnetic susceptibility, collected at 3- to 10-cm intervals at each site, are combined with equally high resolution measurements of digital color reflectance to estimate lithologic variations over the whole sequence. Where magnetic susceptibility and natural gamma were measured in adjacent holes, the between-hole meters composite depth (mcd) scale was refined so that all data from a given site could be combined. A linear regression model is developed that predicts percent $\mathrm{CaCO}_{3}$ from high-resolution measurements of stacked natural gamma emissions, stacked magnetic susceptibility, and digital color reflectance. Over 1300 measurements of percent $\mathrm{CaCO}_{3}$ were made to develop a robust regression equation for each site. An orbitally calibrated chronology for Sites 925-929 relates all data to a common temporal framework. Carbonate and noncarbonate (terrigenous) mass accumulation rates are estimated from 5 to $14 \mathrm{Ma}$ at Sites 925-929. These data are in turn used to evaluate variations in the lysocline from the Miocene to Holocene as a function of depth and time. Over the depth transect, $\mathrm{CaCO}_{3}$ fluxes during the Miocene undergo significant changes, most likely owing to development and intensification of North Atlantic Deep Water during the late Miocene. Terrigenous fluxes show a long-term trend of increasing accumulation in response to Andean uplift and late Miocene development of the Amazon drainage into the Atlantic Ocean.
\end{abstract}

\section{INTRODUCTION}

The Ceara Rise is located in the western equatorial Atlantic Ocean off the coast of South America (Fig. 1). This aseismic feature provides a bathymetric transect through tropical Atlantic waters and passes through the lysocline as well as the present-day mixing zone between North Atlantic Deep Water (NADW) and Antarctic Bottom Water (AABW) (Fig. 2). As such, the Ceara Rise provides a depthprofile of the deep waters most influential to global deep ocean chemistry and circulation.

The sites drilled on the Ceara Rise during Ocean Drilling Program (ODP) Leg 154 provide an opportunity to reconstruct the history of deep ocean chemistry, carbonate sedimentation, and terrigenous fluxes from South America through the late Neogene. Carbonate sedimentary fluxes are required to understand changes in the character of the lysocline and deep water chemistry during the late Neogene. Additionally, terrigenous fluxes to the Ceara Rise during the late Neogene provide insight into the sedimentary contributions of the Amazon basin on orbital to tectonic time scales. Reconstruction of lithologic fluxes over the Ceara Rise bathymetric transect is thus a means to understand the history of carbonate production, carbonate dissolution, and weathering rates, as well as the extent to which these variations are forced by Milankovitch band insolation changes.

${ }^{1}$ Shackleton, N.J., Curry, W.B., Richter, C., and Bralower, T.J. (Eds.), 1997. Proc. ODP, Sci. Results, 154: College Station, TX (Ocean Drilling Program).

${ }^{2}$ Graduate School of Oceanography, University of Rhode Island, Narragansett, RI 02882, U.S.A.tking@gsosunl.gso.uri.edu

${ }^{3}$ Current address: Corning School of Ocean Studies, Maine Maritime Academy, Castine, ME 04420, U.S.A. U.S.A.

${ }^{4}$ Department of Geological Sciences, Brown University, Providence, RI 02912,

${ }^{5}$ Subdepartment for Quaternary Research, Godwin Laboratory, University of Cambridge, Cambridge CB2 3RS, United Kingdom.

${ }^{6}$ College of Oceanic and Atmospheric Sciences, Oregon State University, Corvallis, OR 97331, U.S.A.
The Miocene was marked by large changes in deep-ocean circulation. It is generally agreed that flow of Northern Component Water (NCW) analogous to present-day NADW had initiated by the end of the Miocene, but the time of initiation of NADW is debated. As summarized by Wright et al. (1992), NADW may have initiated anywhere from the Oligocene (Miller and Fairbanks, 1985) to the middle Miocene (Blanc et al., 1980; Schnitker, 1980; Woodruff and Savin, 1989). The development of Antarctic glaciation is also placed during the Miocene (Kennett and Shackleton, 1976; Schnitker, 1980; Woodruff and Savin, 1989; Wright et al., 1992). Although previous studies have taken place on drilled sequences having discontinuous resolution, the Ceara Rise offers the opportunity to develop continuous records spanning the past 14 m.y., and thus offers an opportunity to evaluate the competing hypotheses regarding Miocene deep-water circulation.

The late Neogene is characterized by significant tectonic changes, including the closure of the Isthmus of Panama and the uplift of the Andes (Benjamin et al., 1987). The first development of the Amazon River occurred during the middle Miocene, although tectonic events permitting a connection with the Atlantic and the establishment of present-day Orinoco/Amazon drainage did not occur until the late Miocene (Hoorn et al., 1995). Terrigenous fluxes to the Ceara Rise should document this history of changes in Andean uplift, South American drainage patterns, and erosional fluxes.

During Leg 154, complete sedimentary sequences extending to the Miocene were recovered from the Ceara Rise (Curry, Shackleton, Richter, et al., 1995). The sediments display strong orbital-scale variability. In this paper, lithologic proxies having sub-orbital resolution that extend to the middle Miocene are developed. Methods of converting high-resolution, nonintrusive proxy data to lithologic estimates of carbonate and terrigenous sediment are presented. The changing amplitudes of sedimentation over the Miocene provide information on the response of sedimentation and deep-ocean chemistry to late Neogene boundary conditions. The amplitudes of carbonate flux at each site are examined jointly as a function of depth and time to evaluate the evolution of deep ocean chemistry, the lysocline, 


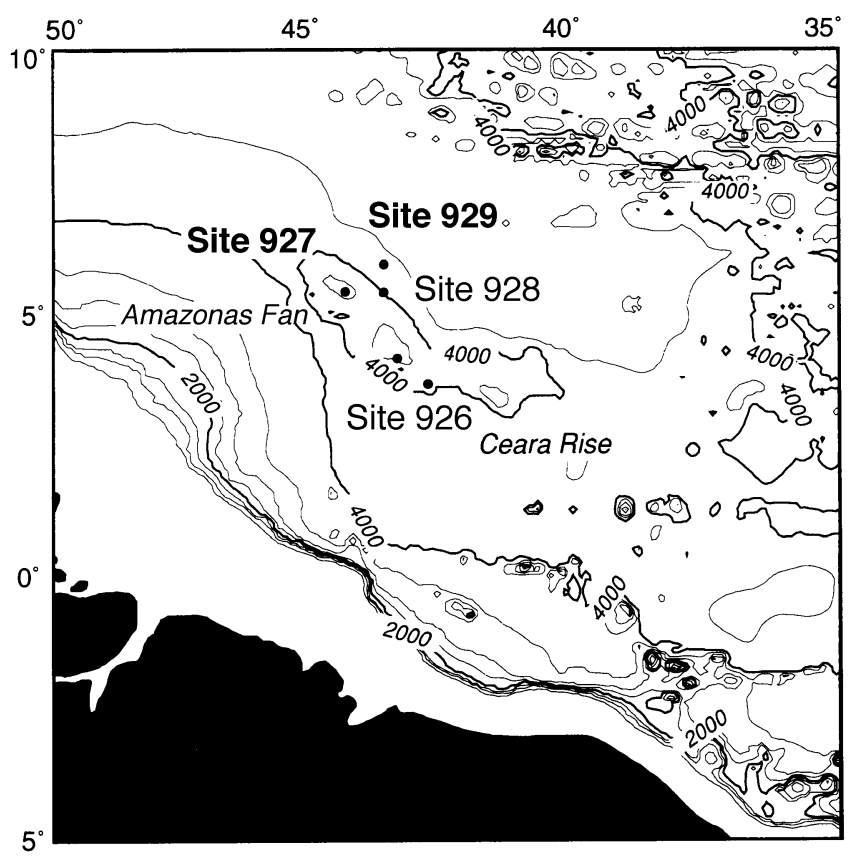

Figure 1. Location of Sites 925-929, Ceara Rise.

and deep ocean circulation. The amplitude of noncarbonate (terrigenous) sediment flux is examined as a function of time to evaluate the effect of late Neogene climatic boundary condition changes.

\section{METHODS \\ Data Reduction}

So that an optimal proxy data set could be used for calibration to lithology, the magnetic susceptibility and natural gamma data collected at 3- to $10-\mathrm{cm}$ resolution during Leg 154 were reduced, cleaned, and corrected as a part of the post-cruise scientific effort. Concurrent with this effort, shipboard measurements of digital color reflectance, collected during Leg 154 and useful in shipboard science, were to a large extent replaced by calibrated measurements of digital reflectance collected post-cruise (Harris et al., this volume).

The reduction of the natural gamma emissions and magnetic susceptibility data included removal of outliers and exclusion of data from disturbed intervals of core. Natural gamma data were corrected for background natural gamma emissions and converted to counts per second. After cleaning each of these data sets, "stacks" of magnetic susceptibility and natural gamma data were made by correlating each core, in turn, to the shipboard spliced record and then averaging the data from multiple holes as briefly described below (additional discussion is given in King and Ellis, this volume). Shipboard composite depths in meters composite depth (mcd) developed for each site over the multiple-cored sequence were based simply on alignment of individual cores (Curry, Shackleton, Richter, et al., 1995). To combine data from adjacent holes into a single record, a more detailed hole-tohole correlation having an accuracy to the order of centimeters is required. A detailed hole-to-hole correlation, accurate to the order of centimeters, was based primarily on the magnetic susceptibility records from each site. Figure 3 illustrates the need for a centimeterscale correlation between holes. Magnetic susceptibility oscillations from adjacent holes on the mcd scale (second panel of Fig. 3), which are accurate to the order of decimeters, are less coherent than the oscillations on the improved revised meters composite depth (rmcd) scale (third panel of Fig. 3). Whereas inverse correlation methods

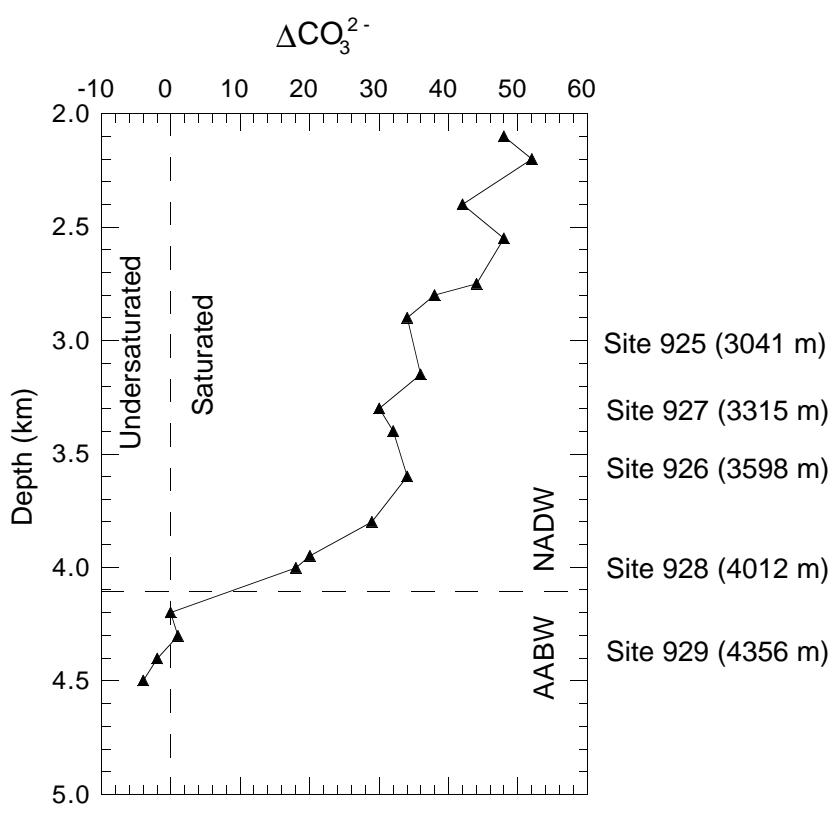

Figure 2. Profile of $\Delta \mathrm{CO}_{3}{ }^{2-}$ from GEOSECS station 42 in the western Atlantic (Broecker and Takahashi, 1978). The present-day mixing zone between NADW and AABW is marked by a horizontal dashed line at around $4100 \mathrm{~m}$. The depths of the Ceara Rise drill sites are given at the right side of the diagram.

were appropriate for detailed hole-to-hole correlations in a previous study of this nature using GRAPE data (Hagelberg et al., 1995) because the magnetic susceptibility has a lower sampling resolution than GRAPE, linear point-to-point correlations were more appropriate for correlating data from individual cores to the shipboard splice. After correlation to the centimeter level, data were examined for additional outliers, "stacked" by rmcd, and then interpolated and smoothed to a uniform 5 -cm resolution for magnetic susceptibility and $10-\mathrm{cm}$ resolution for natural gamma. This procedure was carried out for Sites 925 (0-350 mcd), 926 (0-300 mcd), 927 (0-260 mcd), 928 ( $0-230 \mathrm{mcd})$, and $929(0-150 \mathrm{mcd})$. Figure 3 demonstrates the increased utility of the multiple hole susceptibility and natural gamma data using this method. Additional results bearing on the increased utility of the natural gamma data are summarized by King and Ellis (this volume).

Digital color reflectance measurements were made shipboard using a Minolta CM-2002 hand-held spectrophotometer (Curry, Shackleton, Richter, et al., 1995). However, more detailed and better-calibrated measurements were later made using the Oregon State University (OSU) reflectance instrument (Harris et al., this volume). Where possible, the OSU data in the 550-nm band were used in calibration to lithology. However, over several depth intervals used in this study (140-354 mcd, Site 925; 289-301 mcd, Site 926; 207-232 mcd, Site 928; 139-151 mcd, Site 929), measurements were not made using the OSU instrument owing to time constraints; in those intervals (including all of Site 925), we use the Minolta reflectance values to develop a separate calibration to lithology.

\section{Carbonate Measurements}

Magnetic susceptibility, natural gamma, and digital reflectance to lithology were calibrated to over 1300 calcium carbonate measurements taken from Sites 925-929. At each site, samples were taken at 10- to 20-cm intervals over a number of approximately 400-k.y.-long time slices. The approximate time and depth intervals sampled at 


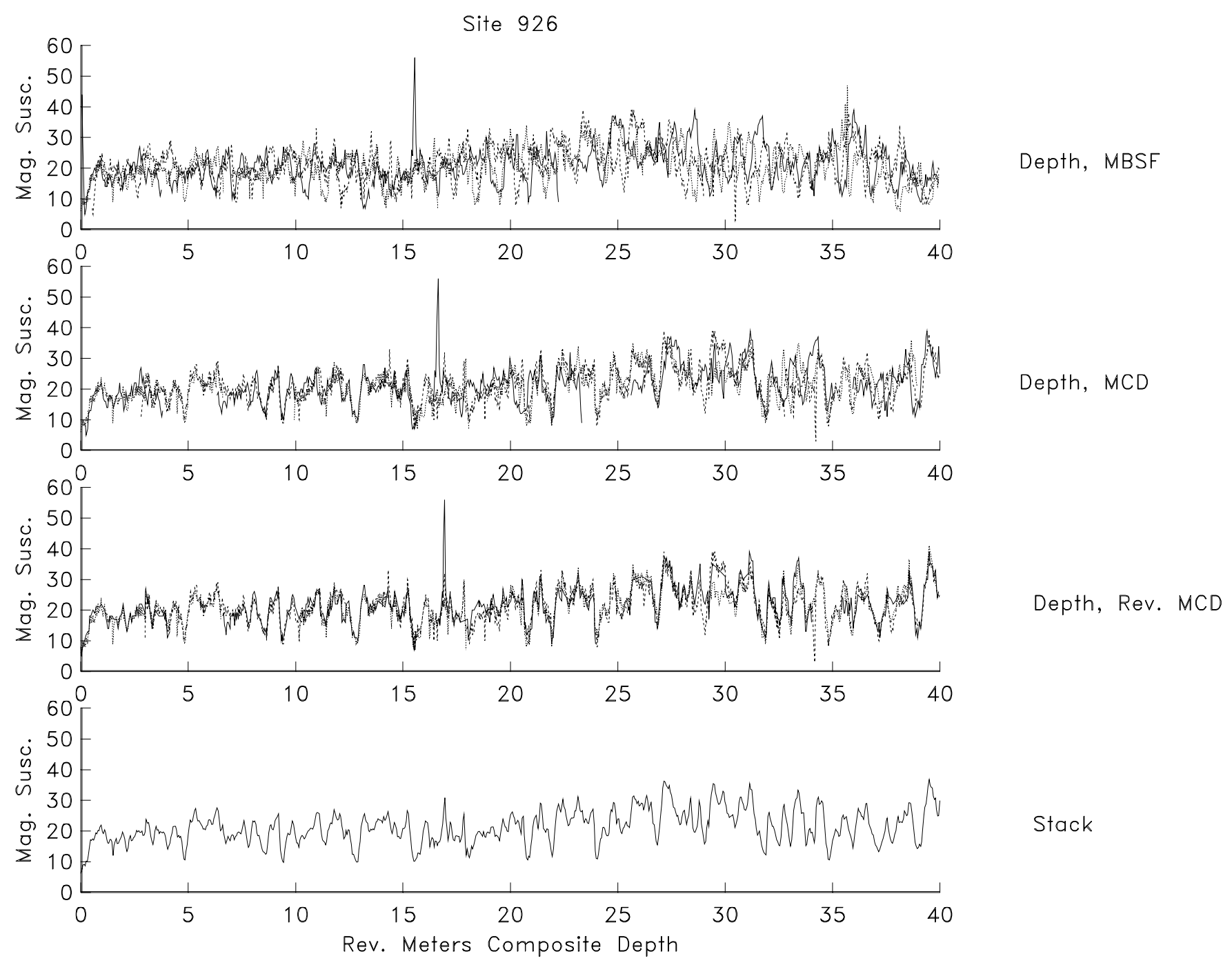

Figure 3. Illustration of procedure used to "stack" multiple hole records of magnetic susceptibility and natural gamma from Sites 925-929. Records of magnetic susceptibility from the top $40 \mathrm{~m}$ of Site 926 are displayed on mbsf depth scale (top), shipboard mcd depths (second from top), revised mcd depths (third from top), and stacked (bottom). See King and Ellis (this volume) for additional detail.

Sites 925-929 included from approximately 2.0-2.4 Ma (the Pliocene 41-k.y. cycle regime), 3.6-4.0 Ma (low latitude 23-k.y. cycle regime), 5-5.4 Ma (time of possible NADW initiation), 9-9.4 Ma (Sites 925-928 only; representative late Miocene), and 13.2-13.6 Ma (Sites 925, 926, 928 only; Miocene). In this way, calibration equations could be developed for each particular time slice and/or for the entire 14-m.y. interval at each site. Shipboard carbonate measurements were also included in the calibrations.

Measurements of percent $\mathrm{CaCO}_{3}$ were obtained from inorganic carbonate measurements made on a Coulometrics Inc. Model 5011 $\mathrm{CO}_{2}$ coulometer with a model 5030 carbonate carbon apparatus. Calcium carbonate concentration was calculated by assuming that all inorganic carbon is present as calcium carbonate. The $\mathrm{CO}_{2}$ coulometer has an accuracy of $0.15 \% \mu \mathrm{g}$ carbon, and the complete procedure has a precision of $\pm 0.52 \mathrm{wt} \%$ calcium carbonate. The calcium carbonate data are given in Table 1.

\section{Linear Regressions}

Stepwise multiple linear regressions were used to predict percent $\mathrm{CaCO}_{3}$ from stacked magnetic susceptibility, stacked natural gamma (where possible), and digital reflectance $(550 \mathrm{~nm})$ data. Each sample containing a percent $\mathrm{CaCO}_{3}$ measurement was matched or interpolated, according to its rmcd depth, to the closest corresponding magnetic susceptibility, natural gamma, and reflectance measurement. If the closest corresponding magnetic susceptibility, natural gamma, or reflectance measurement was greater than $10 \mathrm{~cm}$ away from the percent $\mathrm{CaCO}_{3}$ measurement, that measurement was not entered into the regression. The predominant decimeter-scale variability displayed in all of the sediments, quantified by the typical decorrelation scales of the proxy measurements from depth-domain autocorrelations, guided the choice of the 10-cm cutoff distance for entering measurements into the equation. In practice, because measurements of magnetic susceptibility, natural gamma, and reflectance were made at $10-\mathrm{cm}$ or higher resolution over most cores at each site, individual percent $\mathrm{CaCO}_{3}$ measurements were rarely excluded from the regression equation.

A stepwise multiple linear regression was performed between the percent $\mathrm{CaCO}_{3}$ and proxy data. Regression equations were calculated for each time slice at each site, as well as for each site combining all time slices and shipboard data. Two sets of calibration equations were developed, using both the OSU reflectance data $(550 \mathrm{~nm})$ and the Minolta hand-held (shipboard) reflectance data, because reflec- 
Table 1. Calcium carbonate data, Sites 925-929.

\begin{tabular}{lcc}
\hline $\begin{array}{c}\text { Core, sample, } \\
\text { interval (cm) }\end{array}$ & $\begin{array}{c}\text { Depth } \\
(\mathrm{mcd})\end{array}$ & $\begin{array}{c}\mathrm{CaCO}_{3} \\
(\%)\end{array}$ \\
\hline 154-925C- & & \\
7H-5, 30-32 & 64.34 & 47.48 \\
7H-5, 50-52 & 64.54 & 54.19 \\
7H-5, 70-72 & 64.74 & 52.08 \\
7H-5, 90-92 & 64.94 & 75.32 \\
7H-5, 110-112 & 65.14 & 64.22 \\
7H-5, 130-132 & 65.34 & 37.87 \\
7H-6, 0-2 & 65.54 & 60.36 \\
7H-6, 20-22 & 65.74 & 53.99 \\
7H-6, 40-42 & 65.94 & 50.16 \\
& & \\
\hline
\end{tabular}

Only part of this table is produced here. The entire table is on CD-ROM.

tance data from the OSU instrument was not available at all sites over the depth interval covered in this study (Harris et al., this volume). Results and interpretation of the calibrations developed are discussed below.

\section{Age Control}

An astronomically calibrated time scale for the Miocene portions of Sites 925 and 926 is given by Shackleton and Crowhurst (this volume). To relate lithologic variations in the Miocene portions of Sites 927, 928, and 929 to Sites 925 and 926, these sites must be placed on the same time scale. An age model was developed for the Miocene portions of the composite data from Sites 927, 928, and 929 by correlation to Sites 925 and 926 and corroborated by correlation to the Laskar $(1,1)$ orbital solution (the orbital solution used by Shackleton and Crowhurst., this volume). At Site 927, an age model was developed to $13.323 \mathrm{Ma}$ (308.95 rmcd); at Site 928 , an age model was developed to $14.0 \mathrm{Ma}$ (231.69 rmcd); and at Site 929 , owing to numerous slumps and turbidites below $6 \mathrm{Ma}$, an age model was developed to $5.70 \mathrm{Ma}(150.42 \mathrm{mcd})$ only. Orbitally calibrated age models for the Pliocene-Pleistocene portions of Sites 925-929 are given by Tiedemann and Franz (this volume) and Bickert et al. (Chapter 16, this volume). Age-depth control points for Sites 927, 928, and 929 are given in Table 2. Figure 4 shows age vs. depth plots for Sites 925-929 over the 5-14 Ma interval. Changes in slope of the age-depth plots at 210 mcd and $\sim 260$ mcd (Site 927) indicate regions containing slumps or turbidites, as observed in the Miocene portions of these sites (Curry, Shackleton, Richter, et al., 1995). Additionally, several short breaks in the record, which are either a consequence of slumps/turbidites, the composite depth section, hiatuses, or a combination of the three, are observed at Site 928 previous to $8 \mathrm{Ma}$.

\section{Mass Accumulation Rates}

Mass fluxes of the carbonate and terrigenous (noncarbonate) fractions of the sediment were estimated for the 5-14 Ma portions of Sites 925-929. Mass accumulation rates (MAR) are calculated as the product of percent $\mathrm{CaCO}_{3}$ (or percent non- $\mathrm{CaCO}_{3}$ ), linear sedimentation rate, and dry bulk density:

$$
\begin{gathered}
(\text { non- }) \mathrm{CaCO}_{3} \operatorname{MAR}\left(\mathrm{g} / \mathrm{cm}^{2} / \mathrm{k} . \mathrm{y} .\right)= \\
\frac{\%(\text { non- }) \mathrm{CaCO}_{3} \times \operatorname{LSR}(\mathrm{cm} / \mathrm{k} . \mathrm{y} .) \times \operatorname{dry} \operatorname{density}\left(\mathrm{g} / \mathrm{cm}^{3}\right)}{100}
\end{gathered}
$$

In theory, GRAPE wet bulk density provides a means to obtain ideal high-resolution dry density estimates. However, GRAPE data were marked by several problems during Leg 154, including significant drift problems associated with the counting electronics, electronic cross-talk between GRAPE and $P$-wave, and the need to modify the
Table 2. Age-depth control points; 5-14 Ma for Sites 927 and 928, and 56 Ma for Site 929.

\begin{tabular}{cccccccc}
\hline \multicolumn{2}{c}{ Site 927} & & \multicolumn{2}{c}{ Site 928 } & & \multicolumn{2}{c}{ Site 929 } \\
\cline { 1 - 1 } \cline { 7 - 8 } $\begin{array}{c}\text { Depth } \\
\text { (mcd) }\end{array}$ & $\begin{array}{c}\text { Age } \\
\text { (Ma) }\end{array}$ & & $\begin{array}{c}\text { Depth } \\
\text { (mcd) }\end{array}$ & $\begin{array}{c}\text { Age } \\
(\mathrm{Ma})\end{array}$ & & $\begin{array}{c}\text { Depth } \\
(\mathrm{mcd})\end{array}$ & $\begin{array}{c}\text { Age } \\
(\mathrm{Ma})\end{array}$ \\
\hline 173.92 & 5.015 & & 150.24 & 5.015 & & 141.01 & 5.015 \\
174.01 & 5.019 & & 150.31 & 5.025 & & 142.08 & 5.043 \\
174.30 & 5.034 & & 150.37 & 5.037 & & 142.24 & 5.058 \\
174.47 & 5.037 & & 150.41 & 5.043 & & 142.39 & 5.073 \\
174.88 & 5.049 & & 150.61 & 5.058 & & 142.45 & 5.079 \\
175.11 & 5.061 & & 150.67 & 5.073 & & 142.57 & 5.091 \\
175.39 & 5.073 & & 150.79 & 5.091 & & 142.71 & 5.103 \\
175.62 & 5.079 & & 150.93 & 5.103 & & 142.86 & 5.115 \\
175.68 & 5.088 & & 151.04 & 5.115 & & 142.92 & 5.130 \\
175.97 & 5.100 & & 151.10 & 5.130 & & 143.02 & 5.142 \\
\hline
\end{tabular}

Only part of this table is produced here. The entire table is on CD-ROM.

standard calibration (see "Explanatory Notes" of Curry, Shackleton, Richter, et al., 1995). Thus, GRAPE data were not suitable for calculating mass fluxes. Rather than use the low-resolution shipboard measurements of dry density to calculate mass fluxes that, like GRAPE, display little variability beyond a long-term trend over the first $300 \mathrm{~m}$ of the sedimentary sequence, shipboard-derived curvilinear equations relating dry density measurements to depth in mbsf were used to approximate dry density. These site-specific equations are reproduced in Table 3. Before calculating MAR, this relationship was adjusted for the approximate linear differences between mcd and mbsf scales.

\section{RESULTS AND DISCUSSION Lithologic Calibration}

Regression equations used to predict percent $\mathrm{CaCO}_{3}$, percent variance explained by each equation, and standard errors are given in Tables 4 and 5. Table 4 gives the regression equations derived using shore-based collected reflectance data using the OSU digital reflectance instrument. Table 5 gives equations derived using the shipboard Minolta reflectance measurements. Equations are given both for each time slice sampled, as well as each site over the full depth range sampled. Resulting regression equations are significant at a (1$\alpha=) 0.05$ level using an F-statistic for the multiple regression, although for Site 927, the addition of the reflectance variable to the multiple regression equation did not significantly change the statistically significant relationship derived from magnetic susceptibility and natural gamma alone.

The Ceara Rise is predominantly a two-component sedimentary environment (carbonate and terrigenous sediments), as biogenic opal is not present in significant concentrations at any site during the Neogene (Curry, Shackleton, Richter, et al., 1995). As inferred from shipboard results (Curry, Shackleton, Richter, et al., 1995), magnetic susceptibility and natural gamma data both show general inverse relationships with percent $\mathrm{CaCO}_{3}$, while reflectance shows a positive correlation to percent $\mathrm{CaCO}_{3}$. An inverse magnetic susceptibilitypercent $\mathrm{CaCO}_{3}$ relationship is present because magnetic susceptibility, which is proportional to magnetic mineral concentration and magnetic mineral grain size, often indicates the concentration of terrigenous sediment, and thus is inversely proportional to percent $\mathrm{CaCO}_{3}$ concentration in such a two-component sedimentary environment. Likewise, natural gamma emissions are produced by potassium-, uranium-, and thorium-containing terrigenous material and are also largely proportional to terrigenous concentration. The positive correlation between mid-band reflectance measurements and percent $\mathrm{CaCO}_{3}$ also results from the two-component sedimentary environment in which increased sedimentary percent $\mathrm{CaCO}_{3}$ lightens the sediment and increased terrigenous concentration darkens the sedi- 


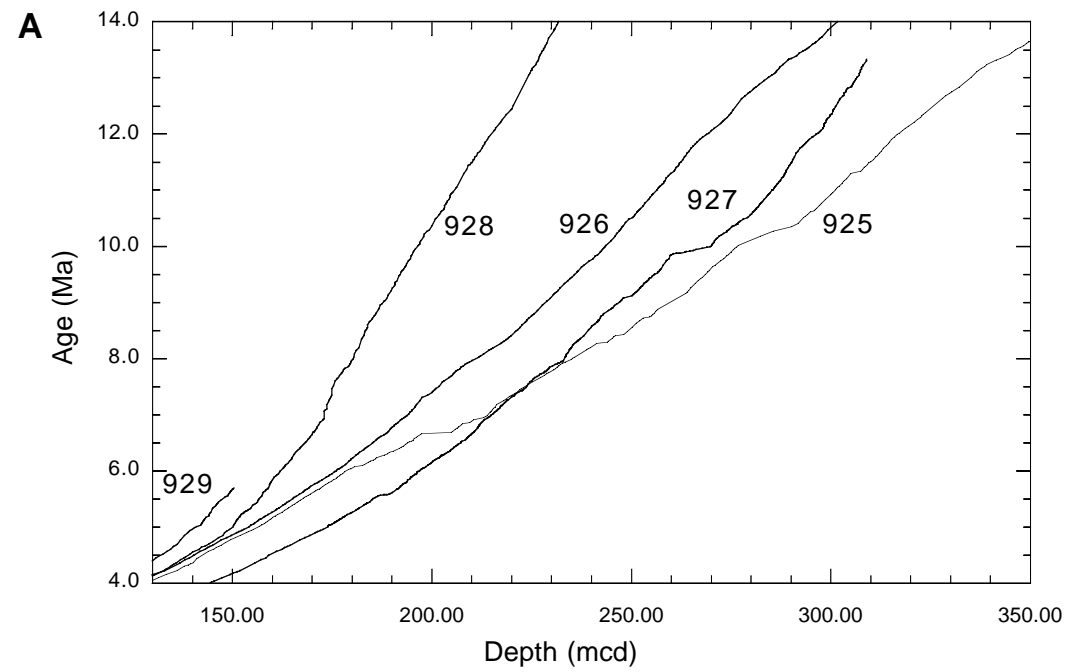

B

925

926

927

928

929
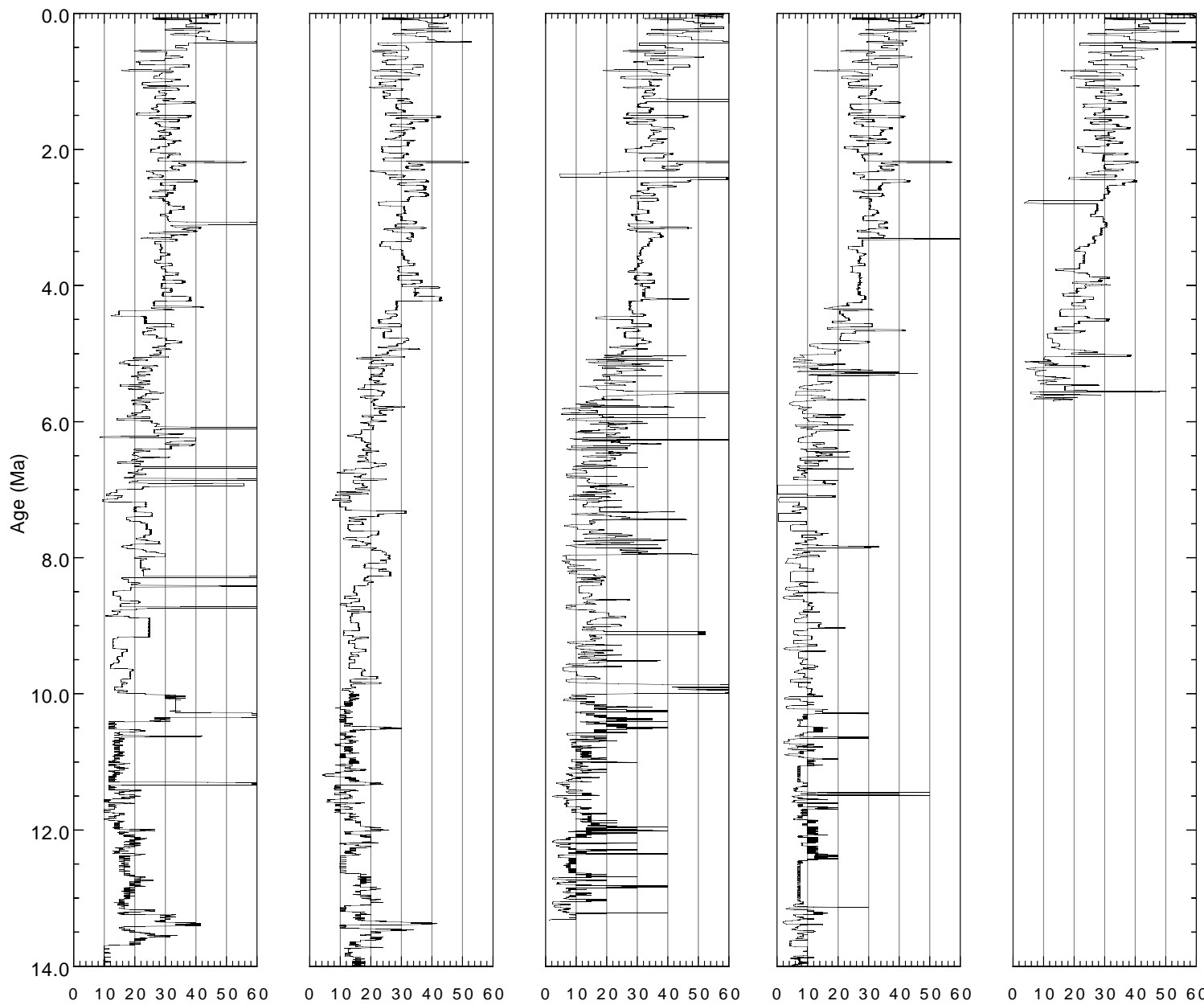

$0 \quad 102030405060$

$0 \quad 102030405060$

$0 \quad 102030405060$ $\mathrm{m} / \mathrm{m} . \mathrm{y}$.

Figure 4. A. Age (Ma) vs. depth (med) for Sites 925-929 in the late Miocene. Age-depth control points for Sites 925 and 926 are from Shackleton and Crowhurst (this volume); for age-depth control for Sites 927, 928, and 929, see Table 2. B. Sedimentation rates, Sites 925-929. 
Table 3. Equations used to predict dry density from depth (mbsf).

\begin{tabular}{ccc}
\hline Site & Equation & $\mathrm{R}$ \\
\hline 925 & $\mathrm{DBD}\left(\mathrm{g} / \mathrm{cm}^{3}\right)=0.49+0.32 \log (\mathrm{mbsf})$ & 0.89 \\
926 & $\mathrm{DBD}\left(\mathrm{g} / \mathrm{cm}^{3}\right)=0.50+0.33 \log (\mathrm{mbsf})$ & 0.89 \\
927 & $\mathrm{DBD}\left(\mathrm{g} / \mathrm{cm}^{3}\right)=0.58+0.27 \log (\mathrm{mbsf})$ & 0.94 \\
928 & $\mathrm{DBD}\left(\mathrm{g} / \mathrm{cm}^{3}\right)=0.55+0.27 \log (\mathrm{mbsf})$ & 0.94 \\
929 & DBD $\left(\mathrm{g} / \mathrm{cm}^{3}\right)=0.43+0.37 \log (\mathrm{mbsf})$ & 0.92 \\
\hline
\end{tabular}

Note: Equations from Moran, pers. comm. (1995).

ment. Additional, less obvious quantitative information regarding the lithologic composition is derived by making optimal use of all bands of the color reflectance data (Harris et al., this volume).

Depth intervals at each site containing both measured and predicted carbonate values were used to additionally verify the regression equations. Figure 5 shows scatter plots relating observed to predicted values of percent $\mathrm{CaCO}_{3}$. In Figure 6, the residuals (observed-predicted) for each set of paired values are displayed as a function of composite depth. From these results, we concluded that, although separate regression equations were developed for each time slice, equations incorporating all carbonate data (including shipboard measurements) and spanning the entire sampled interval at each site appear to be the most robust for generating synthetic carbonate records.

The equations predicting percent $\mathrm{CaCO}_{3}$ for each site were used to generate 14-m.y.-long time series of synthetic percent $\mathrm{CaCO}_{3}$ for Sites 925-929. Over intervals where the OSU reflectance values were not available, the equations based on the Minolta reflectance values were used (all of Site 925; 289-301 mcd, Site 926; 207-232 mcd, Site 928; and 139-151 mcd, Site 929). Synthetic carbonate records for the 0-14 Ma interval are given in Figure 7. Age control for the 0-5 Ma interval at each site come from Tiedemann and Franz (this volume) and Bickert et al. (Chapter 16, this volume), and age control for Site 925 and 926 are from Shackleton and Crowhurst (this volume). The predicted carbonate values developed in this paper for Sites 925 and 926 are similar to those developed by Shackleton and Crowhurst (this volume). As demonstrated by Figure 8, which shows a 3-m.y. interval from Site 926, the independently derived values are in good agreement.

\section{Carbonate Fluxes}

Figure 9 gives $\mathrm{CaCO}_{3}$ mass accumulation estimates for $0-14 \mathrm{Ma}$, and Figure 10 shows non- $\mathrm{CaCO}_{3}$ (terrigenous) mass accumulation rates over the same time interval. Owing to numerous turbidites and slumps, particularly at the deeper sites, long-term trends in the carbonate fluxes are difficult to discern. Although changes in mean $\mathrm{CaCO}_{3}$ flux and terrigenous mass accumulation are evident, the gradients over the Ceara Rise depth transect are difficult to estimate. However, because site-to-site differences in terrigenous flux are not constant and are, in fact, significantly different (Fig. 10), one cannot assume that each site received the same proportional amount of terrigenous material from the Amazon over its history. Thus, it is difficult to reliably gain a view of temporal or bathyl gradients in $\mathrm{CaCO}_{3}$ or terrigenous flux by simply examining the flux time series of the five individual sites. To obtain an overall view of the changes in $\mathrm{CaCO}_{3}$ flux over both depth and time, the data displayed in Figure 9 are smoothed to a 10-k.y. average resolution using a 30-k.y. Gaussian window. The smoothed, evenly spaced $\mathrm{CaCO}_{3}$ flux data are then redisplayed in a shaded contour plot (Fig. 11).

Figure 11 demonstrates a long-term evolution in the depth of the lysocline at the Ceara Rise. Although the Site 929 record only extends to $5.7 \mathrm{Ma}$, Site 929 before 5.7 Ma was predominantly red clay and can be considered to be below the carbonate compensation depth. Therefore, the depth of Site 929 previous to 6 Ma marks the deep end- member of zero $\mathrm{CaCO}_{3}$ flux. The primary emphasis of this paper is the late Miocene, but changes over the past 14 m.y. are displayed to place late Miocene carbonate flux changes in the proper context. Two distinct intervals of lysocline shoaling, where the shallow to deep gradient broadens considerably, occur at about 13.1 and $12.5 \mathrm{Ma}$. The latter interval lasted 200-300 k.y. A shoaling event at $11.8 \mathrm{Ma}$ is marked by the shallowing of the $1 \mathrm{~g} \mathrm{CaCO}_{3} / \mathrm{cm}^{2} / \mathrm{k}$.y. contour to above $3000 \mathrm{~m}$, whereas the $0.5 \mathrm{~g} \mathrm{CaCO}_{3} / \mathrm{cm}^{2} / \mathrm{k}$.y. contour remained at approximately $4000 \mathrm{~m}$. This change in gradient lasted until a deepening event between 10 and $10.5 \mathrm{Ma}$, where the $1 \mathrm{~g} \mathrm{CaCO}_{3} / \mathrm{cm}^{2} / \mathrm{k}$.y. contour deepened to approximately $3900 \mathrm{~m}$. With the exception of a shoaling of the $1 \mathrm{~g} \mathrm{CaCO}_{3} / \mathrm{cm}^{2} / \mathrm{k}$.y. contour from about 7.8 to $7 \mathrm{Ma}$, the period from $10 \mathrm{Ma}$ to approximately $5.5 \mathrm{Ma}$ is marked by semiregular O-oscillations (100-200 k.y.) in the depth of the lysocline and the steepness of the depth gradients.

From carbon isotope data, Wright et al. (1992) inferred a shutdown of Northern Component Water (NCW) at approximately 15.5 Ma (using the Berggren et al., [1985] time scale), which did not resume until 12.5 Ma, after which both NCW and Southern Component Water (SCW) were established. After resumption, however, NCW flow was thought to be reduced relative to present-day flow. An interpretation of the results in Figure 11 that support this scenario is that the changing surface- to deep-gradients in carbonate flux at 13.1 and 12.5 Ma reflect the presence of two deep-water masses, a more corrosive SCW and a less corrosive NCW after 12.5 Ma. However, unlike the interpretation of Wright et al. (1992), evidence is seen in Figure 11 for much more corrosive waters and overall lower $\mathrm{CaCO}_{3}$ fluxes between 11.8 and $10.5 \mathrm{Ma}$, which would argue against $\mathrm{NCW}$ production during this time. The deepening of the $1 \mathrm{~g} \mathrm{CaCO}_{3} /$ $\mathrm{cm}^{2} / \mathrm{k}$.y. contour after $10.5 \mathrm{Ma}$, however, would be consistent with increased NCW, decreasing the corrosiveness of Atlantic deep waters. Wright et al. (1991) infer a sharp reduction in NCW at approximately 9.2 Ma (Berggren et al., [1985] time scale), which lasted until at least $8.9 \mathrm{Ma}$, and another reduction from 6.1 to $5.8 \mathrm{Ma}$. These conclusions do not directly coincide with the observations in Figure 11 where, in comparison to older intervals, deep waters were less corrosive to carbonate. Whereas Wright et al. (1991) observed $\delta^{13} \mathrm{C}$ gradients similar to present-day distributions after $7 \mathrm{Ma}$, the gradients in $\mathrm{CaCO}_{3}$ flux (Fig. 11) show similar patterns to present day, although overall the gradients are larger. $\mathrm{CaCO}_{3}$ fluxes at Site 925 were generally higher than present day from 10.5 to $5 \mathrm{Ma}$; however, fluxes at depth were generally lower. This observation is consistent with reduced but well-established NCW flow in the late Miocene combined with higher surface water $\mathrm{CaCO}_{3}$ flux.

The most significant change in carbonate flux to the Ceara Rise occurs close to the Miocene/Pliocene boundary, around 5.1 Ma. This event is marked by a deepening of the $1 \mathrm{~g} \mathrm{CaCO}_{3} / \mathrm{cm}^{2} / \mathrm{k}$.y. contour to below $4200 \mathrm{~m}$. The strong shallow to deep gradients that were observed from 14 to $5.1 \mathrm{Ma}$ essentially disappear. This event likely marks a significant change in deep ocean chemistry, possibly the onset of strong NCW flow analogous to modern NADW. Although the data of Wright et al. (1991) only extended to about 5.5 Ma, these authors inferred strong NCW flow after $5.8 \mathrm{Ma}$ from their limited data. After 5.1 Ma, significantly higher $\mathrm{CaCO}_{3}$ fluxes are observed over the full depth transect, both at the shallowest site (Site 925, $3100 \mathrm{~m}$ ) and Site 929 . Overall increased $\mathrm{CaCO}_{3}$ production likely plays a role in the diminished gradients observed. Although isotopic data are required to constrain the relative magnitudes of NCW and SCW flow during this time, the corrosiveness of waters reaching a depth of over $4000 \mathrm{~m}$ was also significantly reduced. Finally, the early Pleistocene was marked by a resumed shallowing of the lysocline, with 41-k.y. oscillations in $\mathrm{CaCO}_{3}$ flux indicating glacial-interglacial changes in deep water flow, broadening to $\sim 100-\mathrm{k}$.y. oscillations in the late Pleistocene. It is clear from Figure 11 that while Miocene shallow 
Table 4. Regression equations used for prediction of percent $\mathrm{CaCO}_{3}$.

\begin{tabular}{|c|c|c|c|c|c|c|c|c|}
\hline $\begin{array}{l}\text { Depth } \\
\text { (mcd) }\end{array}$ & $\begin{array}{l}\text { Age } \\
(\mathrm{Ma})\end{array}$ & $\mathrm{N}$ & Intercept & $\begin{array}{c}\text { Natural } \\
\text { gamma } \\
\text { (counts/s) }\end{array}$ & $\begin{array}{l}\text { Reflectance } \\
\quad(\%)\end{array}$ & $\begin{array}{c}\text { Magnetic } \\
\text { susceptibility } \\
\text { (SI) }\end{array}$ & $\mathrm{R}^{2}$ & $\begin{array}{l}\text { Standard } \\
\text { error }\end{array}$ \\
\hline \multicolumn{9}{|l|}{ Site 926} \\
\hline & & 331 & 58.99 & -1.130 & 0.816 & -0.826 & 0.93 & 4.3 \\
\hline $62-75$ & $\sim 1.9-2.4$ & 99 & 50.09 & -1.420 & 1.370 & -0.932 & 0.90 & 4.5 \\
\hline $113-125$ & $\sim 3.6-4.0$ & 111 & 35.14 & -0.990 & 1.420 & -0.280 & 0.86 & 3.6 \\
\hline $155-163$ & $\sim 5.0-5.4$ & 83 & 66.47 & 0.358 & 0.428 & -1.260 & 0.74 & 4.9 \\
\hline $230-234$ & $\sim 9.1-9.4$ & 39 & 54.55 & -0.524 & 0.663 & -0.242 & 0.76 & 3.3 \\
\hline \multicolumn{9}{|l|}{ Site 927} \\
\hline & & 107 & 89.88 & -1.080 & 0.070 & -1.450 & 0.92 & 3.8 \\
\hline $139-141$ & $\sim 3.8-3.9$ & 14 & 33.42 & -0.882 & 1.620 & -0.360 & 0.93 & 3.1 \\
\hline $177-182$ & $\sim 5.1-5.3$ & 27 & 62.39 & -0.494 & 0.636 & -0.710 & 0.90 & 2.2 \\
\hline $252-260$ & $\sim 9.2-9.8$ & 66 & 92.5 & 0.200 & -0.028 & -2.300 & 0.70 & 3.6 \\
\hline \multicolumn{9}{|l|}{ Site 928} \\
\hline & & 214 & 28.37 & -0.401 & 1.410 & -0.542 & 0.91 & 5.3 \\
\hline $3-87$ & $\sim 0.1-2.7$ & 45 & 56.16 & -1.120 & 0.842 & -0.941 & 0.83 & 6.6 \\
\hline $116-129$ & $\sim 3.6-4.1$ & 41 & 62.25 & -1.260 & 0.533 & -0.658 & 0.86 & 3.6 \\
\hline $147-159$ & $\sim 4.8-5.7$ & 118 & 33.7 & -0.511 & 1.300 & -0.453 & 0.92 & 3.7 \\
\hline $167-234$ & $\sim 6.4-14$ & 12 & 34.06 & -0.417 & 1.050 & -0.119 & 0.80 & 9.2 \\
\hline \multicolumn{9}{|l|}{ Site 929} \\
\hline & & 211 & -0.11 & -0.337 & 2.340 & -0.527 & 0.88 & 7.0 \\
\hline $0-19$ & $\sim 0.0-0.4$ & 156 & 13.77 & -0.403 & 1.540 & -0.585 & 0.76 & 7.7 \\
\hline $113-138$ & $\sim 3.6-4.9$ & 48 & 56.29 & -1.180 & 0.705 & -0.619 & 0.91 & 3.9 \\
\hline
\end{tabular}

Note: Measurements taken with the OSU instrument.

Table 5. Regression equations used for prediction of percent $\mathrm{CaCO}_{3}$.

\begin{tabular}{|c|c|c|c|c|c|c|c|c|}
\hline $\begin{array}{l}\text { Depth } \\
\text { (mcd) }\end{array}$ & Age (Ma) & $\mathrm{N}$ & Intercept & $\begin{array}{c}\text { Natural } \\
\text { gamma } \\
\text { (counts/s) }\end{array}$ & $\begin{array}{c}\text { Reflectance } \\
(\%)\end{array}$ & $\begin{array}{c}\text { Magnetic } \\
\text { susceptibility } \\
\text { (SI) }\end{array}$ & $\mathrm{R}^{2}$ & $\begin{array}{l}\text { Standard } \\
\text { error }\end{array}$ \\
\hline \multicolumn{9}{|l|}{ Site 925} \\
\hline & & 195 & 59.48 & -1.025 & 0.770 & -0.076 & 0.86 & 4.7 \\
\hline $119-126$ & $\sim 3.6-4.0$ & 38 & 39.17 & 0.160 & 0.930 & -0.746 & 0.85 & 3.6 \\
\hline $153-159$ & $\sim 5.0-5.4$ & 30 & 82.85 & 0.150 & 0.110 & -1.876 & 0.77 & 5.3 \\
\hline $260-273$ & $\sim 9.0-9.4$ & 101 & 73.69 & -0.250 & 0.320 & -0.799 & 0.78 & 2.6 \\
\hline $341-346$ & $\sim 13.0-13.4$ & 26 & 58.38 & -0.960 & 0.970 & -1.976 & 0.91 & 4.6 \\
\hline \multicolumn{9}{|l|}{ Site 926} \\
\hline & & 337 & 70.15 & -1.000 & 0.670 & -1.355 & 0.93 & 4.4 \\
\hline $62-76$ & $\sim 2.0-2.4$ & 100 & 48.93 & -0.790 & 1.370 & -1.204 & 0.9 & 4.5 \\
\hline $113-125$ & $\sim 3.6-4.0$ & 110 & 21.62 & 0.220 & 1.760 & -0.628 & 0.91 & 2.9 \\
\hline $155-163$ & $\sim 5.0-5.4$ & 86 & 71.92 & 0.640 & 0.400 & -1.649 & 0.84 & 3.7 \\
\hline $230-234$ & $\sim 9.0-9.4$ & 41 & 71.36 & -1.090 & 0.450 & -0.687 & 0.72 & 3.4 \\
\hline \multicolumn{9}{|l|}{ Site 927} \\
\hline & & 126 & 78.98 & -0.973 & 0.320 & -1.110 & 0.89 & 4.3 \\
\hline $179-184$ & $\sim 5.2-5.4$ & 42 & 41.34 & -0.391 & 1.180 & -0.175 & 0.65 & 4.1 \\
\hline $252-260$ & $\sim 9.2-9.8$ & 69 & 85 & 0.129 & 0.154 & -2.130 & 0.71 & 3.5 \\
\hline \multicolumn{9}{|l|}{ Site 928} \\
\hline & & 328 & 58.04 & -1.330 & 0.760 & -0.697 & 0.76 & 9.4 \\
\hline $0-77$ & $\sim 0-2.4$ & 77 & 61.22 & -1.140 & 0.400 & -0.775 & 0.65 & 9.1 \\
\hline $82-129$ & $\sim 2.5-4.0$ & 54 & 10.5 & -0.690 & 1.980 & -0.231 & 0.89 & 3.2 \\
\hline $132-208$ & $\sim 4.2-10.8$ & 137 & 16.99 & -0.420 & 1.870 & -0.519 & 0.95 & 3.3 \\
\hline $217-244$ & $\sim 12.0-14.0$ & 58 & 18.2 & -1.000 & 1.470 & -0.788 & 0.83 & 9.2 \\
\hline \multicolumn{9}{|l|}{ Site 929} \\
\hline & & 294 & -11.14 & -0.874 & 2.930 & -0.591 & 0.9 & 7.0 \\
\hline $0-19$ & $\sim 0-0.5$ & 160 & 4.52 & -0.800 & 2.130 & -0.673 & 0.78 & 7.9 \\
\hline $67-121$ & $\sim 2.0-4.0$ & 56 & 70.48 & -1.500 & 0.500 & -0.934 & 0.93 & 4.1 \\
\hline $144-149$ & $\sim 5.3-5.5$ & 78 & 4.13 & -0.700 & 2.160 & -0.414 & 0.9 & 3.7 \\
\hline
\end{tabular}

Note: Measurements taken using the shipboard Minolta spectrophotometer.

water (Site 925) $\mathrm{CaCO}_{3}$ fluxes were higher than those of the Pleistocene, Pleistocene deep waters were typically not as corrosive as those of the late Miocene (5-14 Ma).

In summary, shallow-to-deep gradients over the Ceara Rise depth transect suggest a long-term shoaling of the lysocline from 14 to 11.5 $\mathrm{Ma}$, with a subsequent deepening from 10.5 to $5 \mathrm{Ma}$. Significant deepening and increased $\mathrm{CaCO}_{3}$ fluxes occurred during the Pliocene, followed by a shoaling of the lysocline into the Pleistocene. Superimposed on these changes are variations in shallow water (Sites 925, $926,927) \mathrm{CaCO}_{3}$ fluxes that demonstrate a mean increase from Miocene to Pliocene.

\section{Terrigenous Fluxes}

Terrigenous fluxes at the Ceara Rise during the Miocene and terrigenous compositional changes remain to be studied in detail. However, the evolution of terrigenous fluxes, as observed in Figure 10, demonstrate some distinct events superimposed upon long-term trends. The magnitude of terrigenous flux received at each site appears to be jointly a function of proximity to the Amazon Fan and water depth (Figs. 1, 10). Site 925, located centrally on the Ceara Rise and the shallowest site, receives the highest mean terrigenous flux over the past 14 m.y. Sites 927 and 929, located on the northern side 
of the Ceara Rise, receive overall higher terrigenous fluxes than Sites 928 and 926, which are located more distal to the Amazon Fan. With the exception of Site 925 , the terrigenous sedimentation at all sites displays an overall increase from the late Miocene to Holocene. Site 925 , on the other hand, displays high amplitude variability in terrigenous fluxes during the Miocene and late Pliocene, followed by a decrease from Pliocene to Holocene.

The long-term increase in terrigenous fluxes must reflect the increased tectonic and climate-induced weathering and delivery of terrigenous fluxes from South America. The most significant event recorded at all sites is the $\sim 4.5$ - to 5-Ma increase in terrigenous flux. While tectonic events associated with closure of the Isthmus of Panama cannot be excluded, this increase most likely reflects the late Miocene onset of South American drainage into the Atlantic Ocean via the newly formed Amazon River (Hoorn et al., 1995). The climatological and oceanographic changes leading to the coincidence of this event and the Miocene/Pliocene change in $\mathrm{CaCO}_{3}$ fluxes, the two most significant events occurring on the Ceara over the past 14 m.y., remain to be studied by incorporating these data with isotopic and other geochemical indicators.

All sites are distinguished by several events during the Miocene in addition to the slumps and turbidites that characterize Sites 925, 928, and 929 in particular (Curry, Shackleton, Richter, et al., 1995). All sites display a strong drop in terrigenous fluxes between 5.5 and 4.5 Ma, preceding the Pliocene increase in flux. Similarly, several distinct changes in terrigenous flux are recorded at Sites 925-928 at $\sim 13.5 \mathrm{Ma}, 12 \mathrm{Ma}, 10.7 \mathrm{Ma}, 9.5-9.7 \mathrm{Ma}$, and 8.1 Ma. This last event appears to be associated with a change in the clay composition of the sediments from kaolinite and smectite to illite, as deduced from natural gamma data (Curry, Shackleton, Richter, et al., 1995). Additional study involving mineralogic proxies are required to determine if this event signifies the first delivery of South American sediments to the Atlantic via the Amazon drainage system, which is thought to have occurred in the late Miocene (Hoorn et al., 1995)

\section{CONCLUSIONS}

1. The combination of high quality shipboard magnetic susceptibility, natural gamma, and digital reflectance data provides excellent proxies for lithologic composition (carbonate-terrigenous) at Ceara Rise Sites 925-929. These proxies allow near-continuous records of percent $\mathrm{CaCO}_{3}$, percent terrigenous, and mass fluxes to be developed for the past 14 m.y. (past 5.7 m.y. at Site 929).

2. Reconstruction of carbonate fluxes on the Ceara Rise depth transect constrain lysocline depth and deep water $\mathrm{CO}_{3}=$ gradients from the late Miocene to present. The data presented here show evidence for less corrosive waters at the shallow sites, possibly indicating the onset of a NADW source by $10.5 \mathrm{Ma}$. $\mathrm{CaCO}_{3}$ fluxes at the shallow sites are higher than present day, and surface-to-deep gradients are generally stronger than present day from 10.5 to $5 \mathrm{Ma}$.

3. The most significant change in $\mathrm{CaCO}_{3}$ fluxes over the Ceara Rise depth transect over the past $14 \mathrm{~m}$.y. occurs at approximately 5.1 $\mathrm{Ma}$, and is marked by a strong deepening of the lysocline. Whereas $\mathrm{CaCO}_{3}$ fluxes at the shallow sites increased, the $1 \mathrm{~g} \mathrm{CaCO}_{3} / \mathrm{cm}^{2} / \mathrm{k}$.y. contour deepened to below $4200 \mathrm{~m}$. Significant deepening continued during the Pliocene, followed by a shoaling of the lysocline to its present-day position.
4. The most significant change in terrigenous fluxes on the Ceara Rise occurs as a long-term increase, beginning in the latest Miocene and continuing to Holocene at most sites. Late Miocene events common to all sites are related to South American tectonic events and reorganization of northern South American drainage patterns (e.g., the Amazon) during this time.

5. Combination of the carbonate and terrigenous flux data presented here with carbon isotopic data from the same sites as well as other geochemical and mineralogical proxies will permit a high resolution and near-continuous reconstruction of deep water changes through the Miocene. Continued study will also help to further constrain climatological and oceanographic changes that would explain the coincidence of the late Miocene/Pliocene increase in terrigenous flux and the $\sim 5.1 \mathrm{Ma}$ lysocline deepening.

\section{REFERENCES}

Benjamin, M., Johnson, N.M., and Naeser, C.W., 1987. Recent rapid uplift in the Bolivian Andes: evidence from fission-track dating. Geology, 15:680-683.

Berggren, W.A., Kent, D.V., and Van Couvering, J.A., 1985. The Neogene, Part 2. Neogene geochronology and chronostratigraphy. In Snelling, N.J. (Ed.), The Chronology of the Geological Record. Geol. Soc. London Mem., 10:211-260.

Blanc, P.-L., Rabussier, D., Vergnaud-Grazzini, C., and Duplessy, J.-C., 1980. North Atlantic deep water formed by the later middle Miocene. Nature, 283:553-555.

Broecker, W.S., and Takahashi, T., 1978. The relationship between lysocline depth and in-situ carbonate ion concentration. Deep-Sea Res. Part A, 25:65-95.

Curry, W.B., Shackleton, N.J., Richter, C., et al., 1995. Proc. ODP, Init. Repts., 154: College Station, TX (Ocean Drilling Program).

Hagelberg, T.K., Pisias, N.G., Shackleton, N.J., Mix, A.C., and Harris, S., 1995. Refinement of a high-resolution, continuous sedimentary section for studying equatorial Pacific Ocean paleoceanography, Leg 138. In Pisias, N.G., Mayer, L.A., Janecek, T.R., Palmer-Julson, A., and van Andel, T.H. (Eds.), Proc. ODP, Sci Results, 138: College Station, TX (Ocean Drilling Program), 31-46.

Hoorn, C., Guerrero, J., Sarmiento, G.A., and Lorente, M.A., 1995. Andean tectonics as a cause for changing drainage patterns in Miocene northern South America. Geology, 23:237-240.

Kennett, J.P., and Shackleton, N.J., 1976. Oxygen isotopic evidence for the development of the psychrosphere 38 Myr ago. Nature, 260:513-515.

Miller, K.G., and Fairbanks, R.G., 1985. Oligocene to Miocene carbon isotope cycles and abyssal circulation changes. In Sundquist, E.J., and Broecker, W.S. (Eds.), The Carbon Cycle and Atmospheric $\mathrm{CO}_{2}$ : Natural Variations Archean to Present. Geophys. Monogr., Am. Geophys. Union, 32:469-486.

Schnitker, D., 1980. North Atlantic oceanography as possible cause of Antarctic glaciation and eutrophication. Nature, 284:615-616.

Woodruff, F., and Savin, S.M., 1989. Miocene deepwater oceanography. Paleoceanography, 4:87-140.

Wright, J.D., Miller, K.G., and Fairbanks, R.G., 1991. Evolution of modern deepwater circulation: evidence from the late Miocene Southern Ocean. Paleoceanography, 6:275-290.

, 1992. Early and middle Miocene stable isotopes: implications for deepwater circulation and climate. Paleoceanography, 7:357-389.

Date of initial receipt: 30 November 1995

Date of acceptance: 16 April 1996

Ms 154SR-116 
925

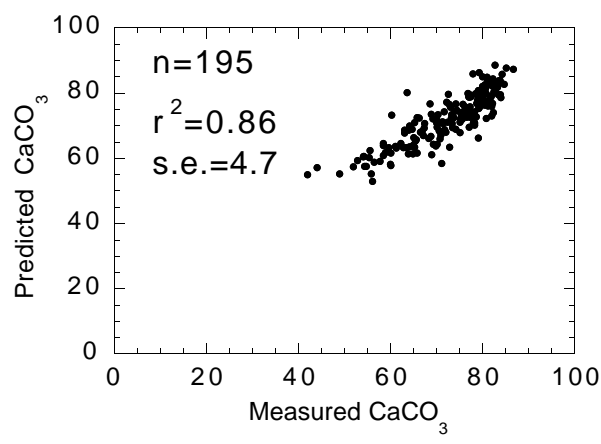

927

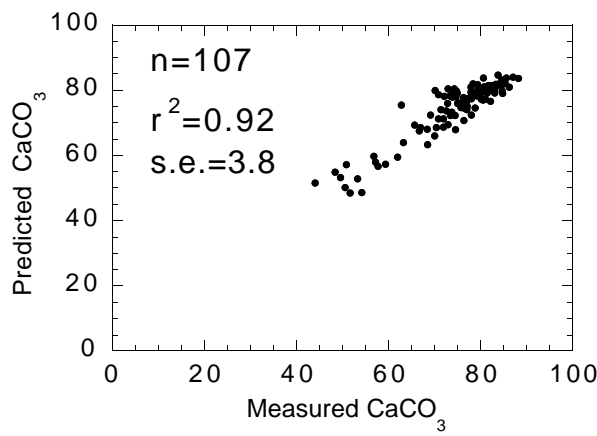

929

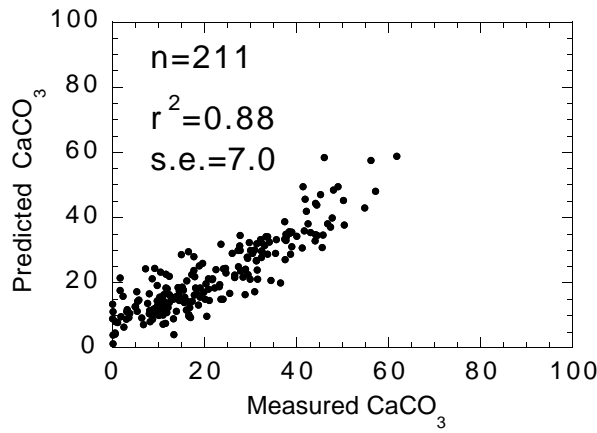

926

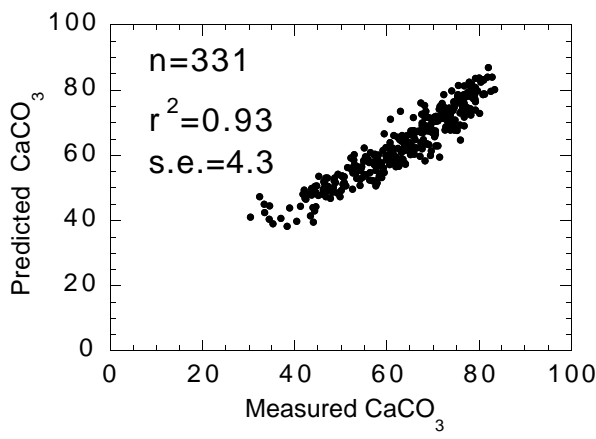

928

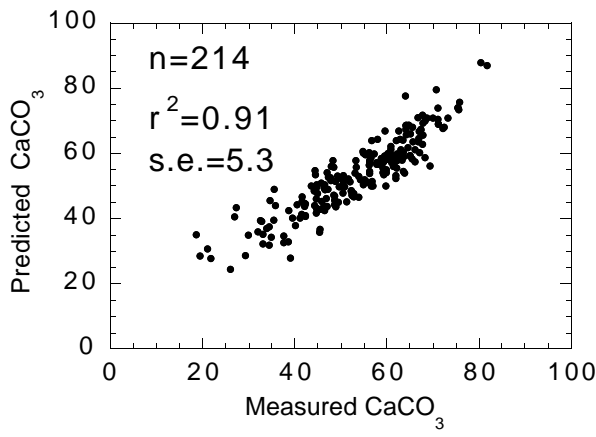

Figure 5. Fit between observed and predicted measurements of percent $\mathrm{CaCO}_{3}$. With the exception of Site 925 , the correlation is based on the shipboard reflectance-based equation (Table 5). Equations used to relate observed to predicted values of percent $\mathrm{CaCO}_{3}$ are those for each entire site and are given in Table 4. 
T.A. KING ET AL.

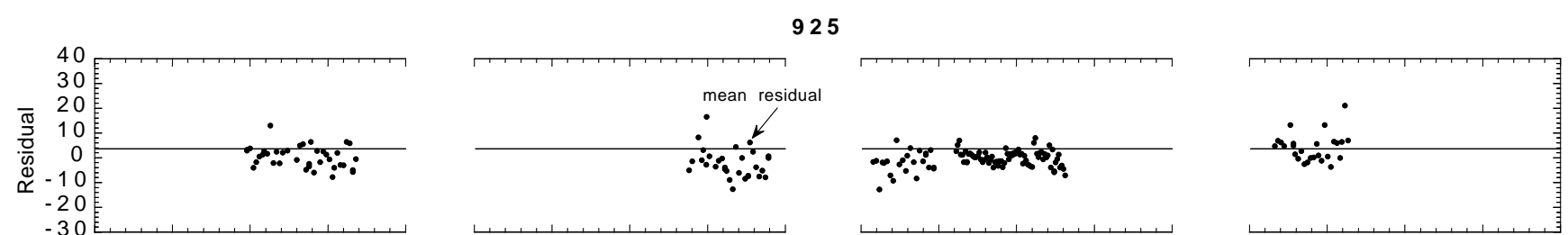

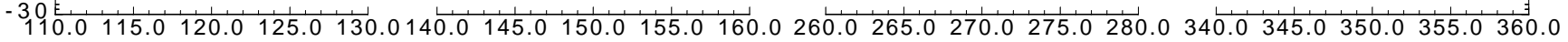
MCD
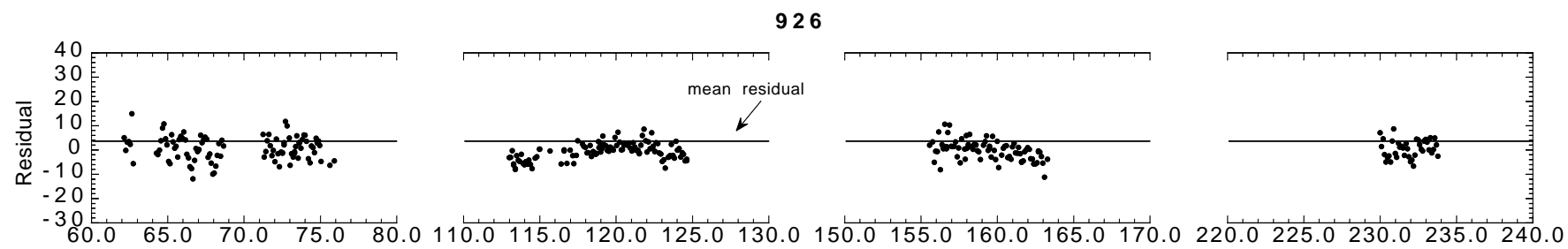

MCD
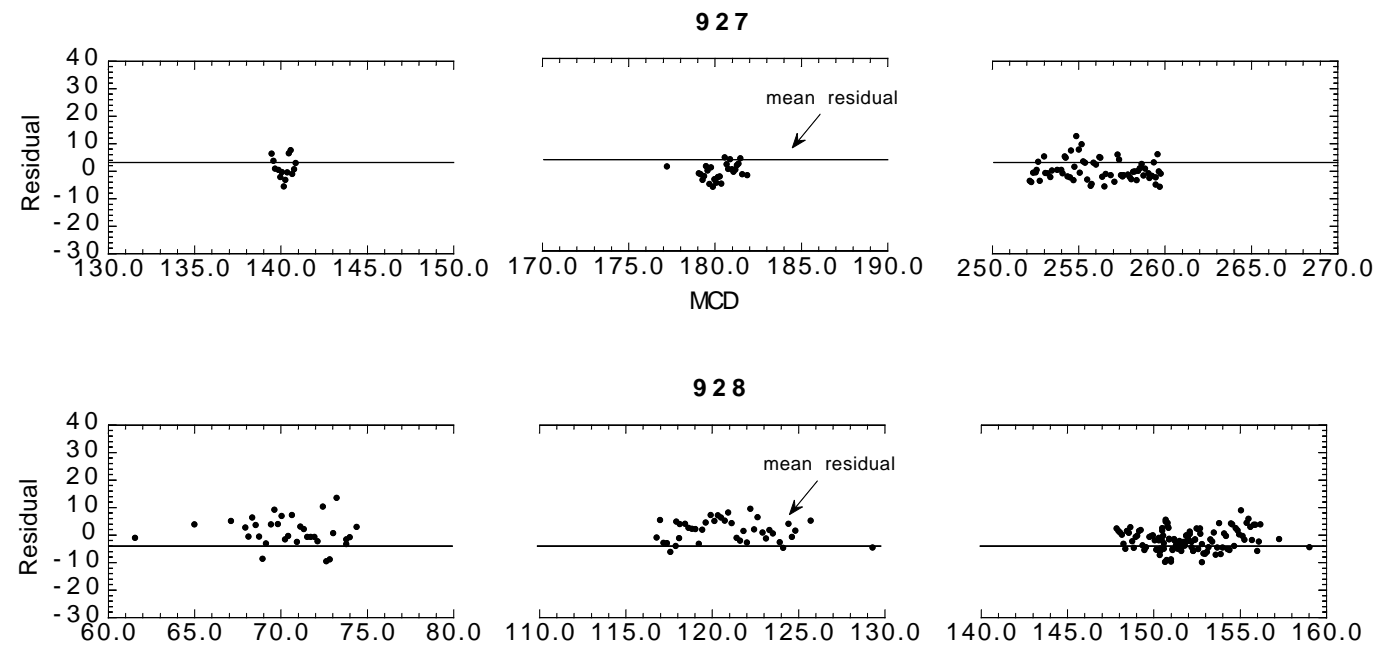

MCD

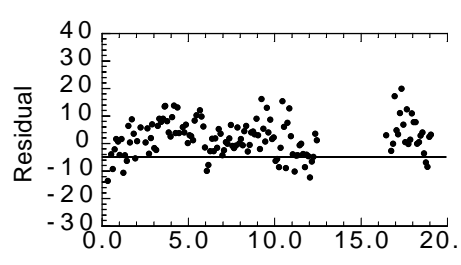

929

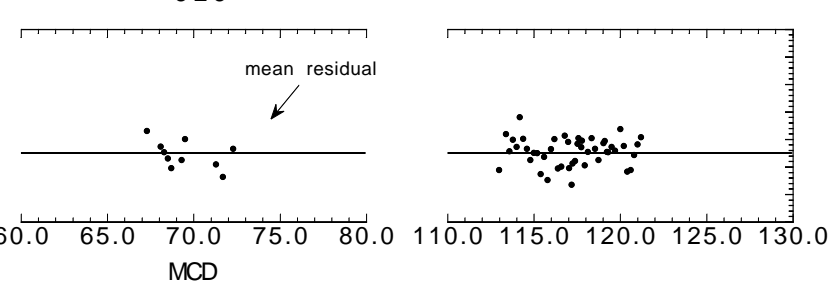

Figure 6. Residuals of percent $\mathrm{CaCO}_{3}$ regressions (observed percent $\mathrm{CaCO}_{3}$ minus predicted percent $\mathrm{CaCO}_{3}$ ) vs. depth in mcd, Sites $925-929$. 
MIOCENE EVOLUTION OF CARBONATE SEDIMENTATION

A

925

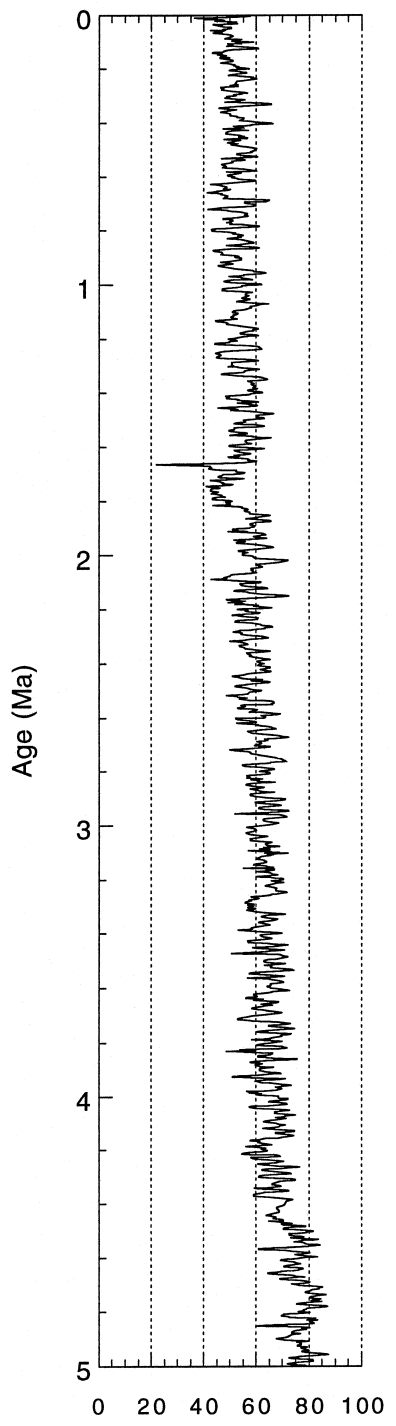

926

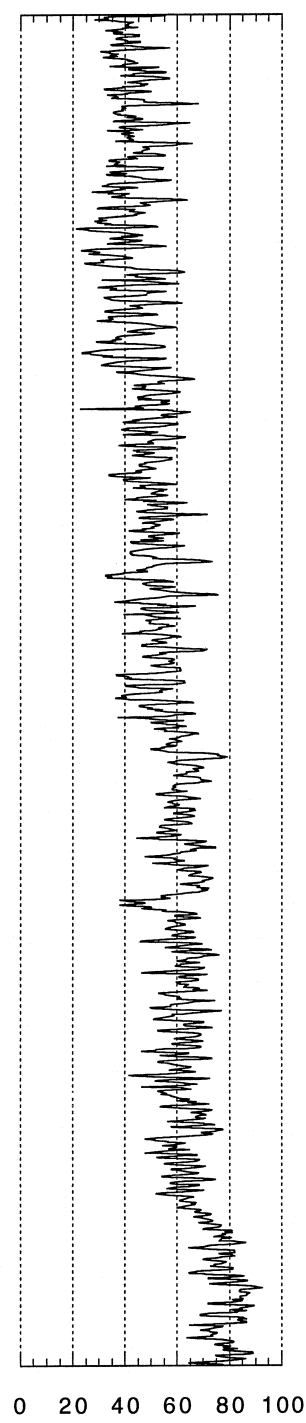

927

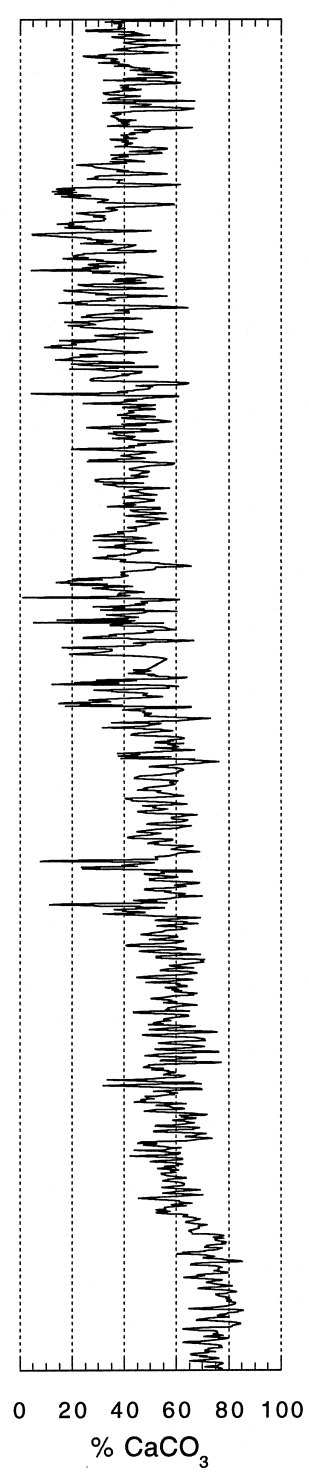

928

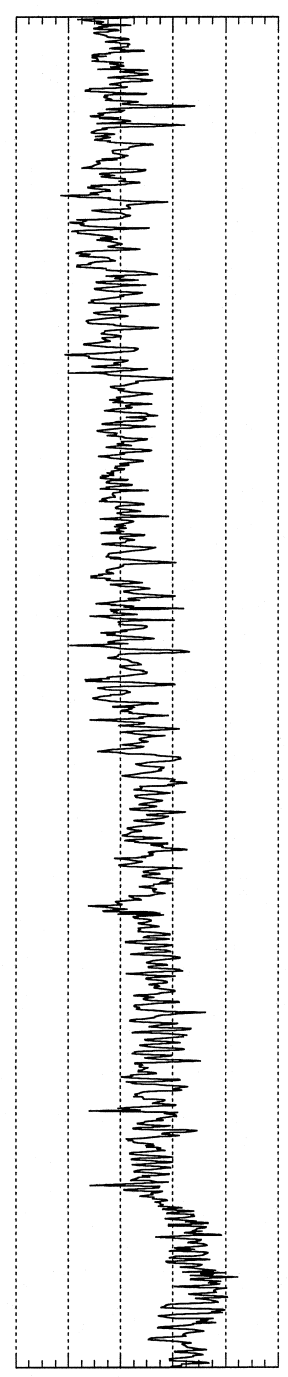

$0 \quad 20 \quad 40 \quad 60 \quad 80 \quad 100$
929

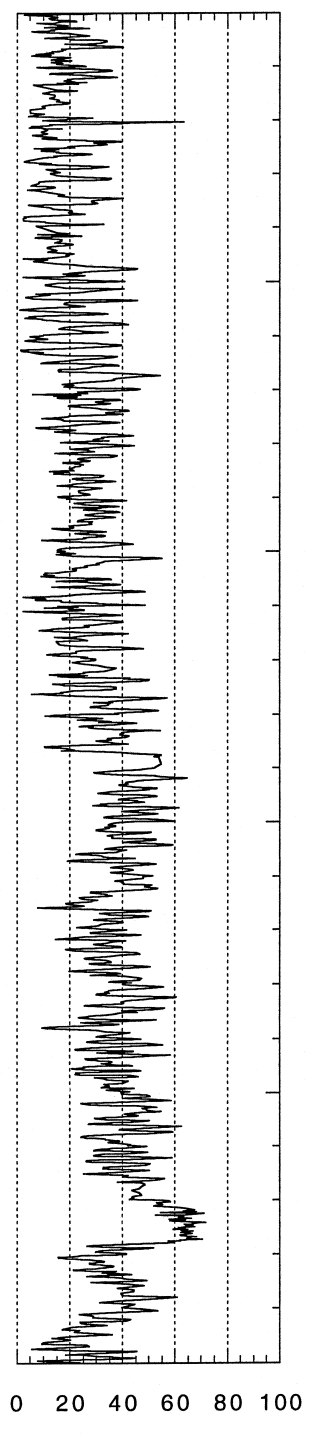

Figure 7. Time series of percent $\mathrm{CaCO}_{3}$, Sites 925-929. A. 0-5 Ma. B. 5-8 Ma. C. 8-11 Ma. D. 11-14 Ma. 
T.A. KING ET AL.
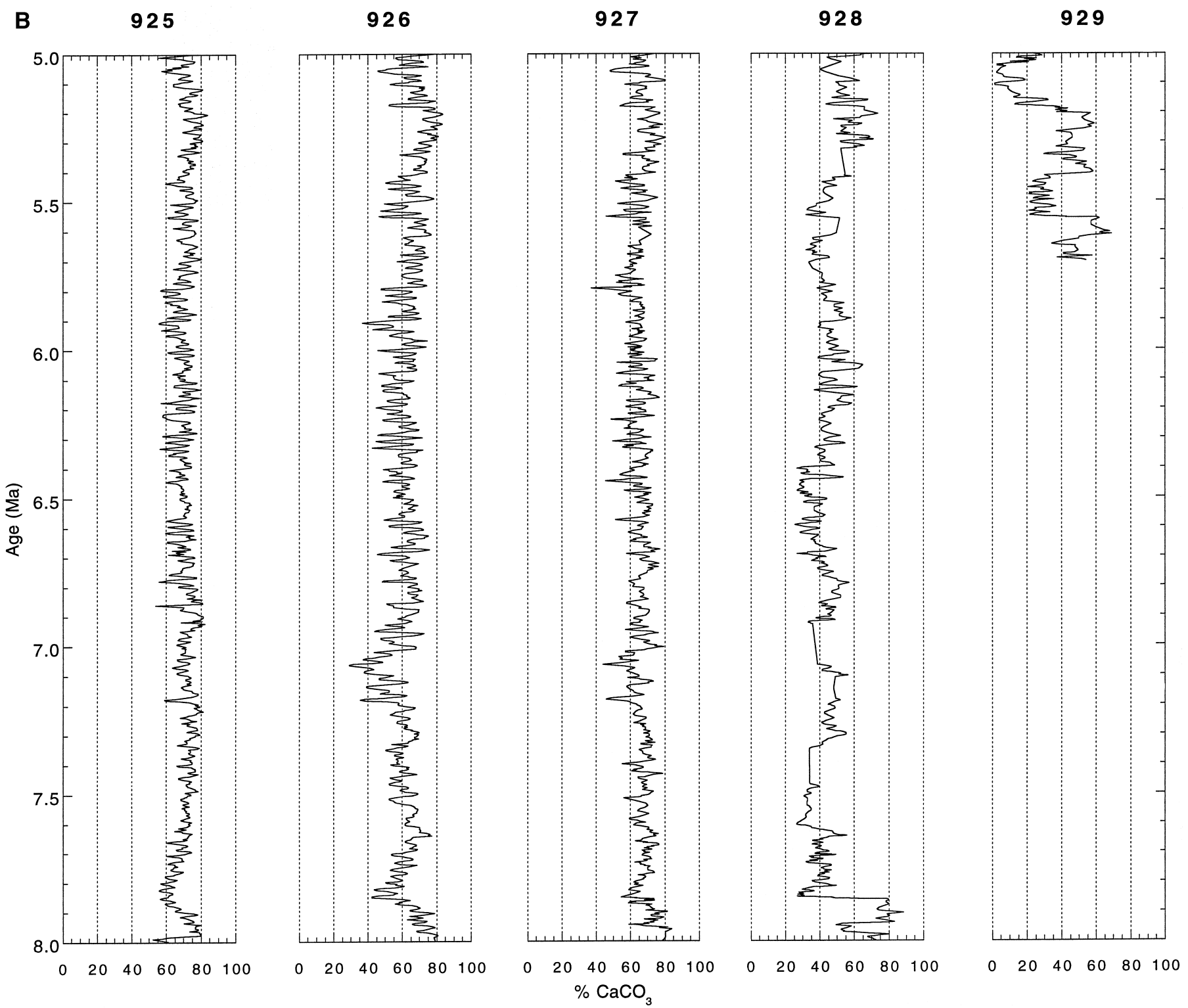

Figure 7 (continued). 
MIOCENE EVOLUTION OF CARBONATE SEDIMENTATION

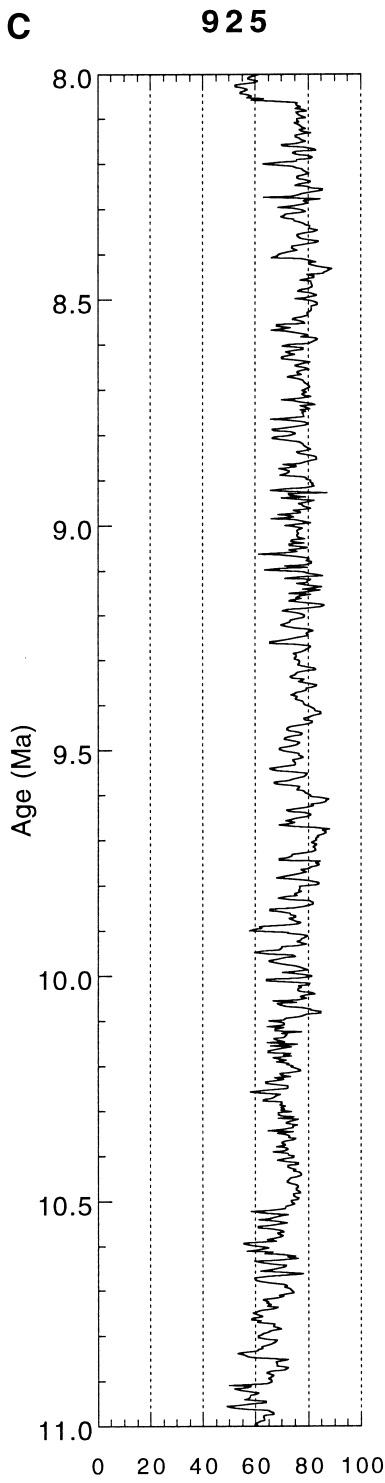

926

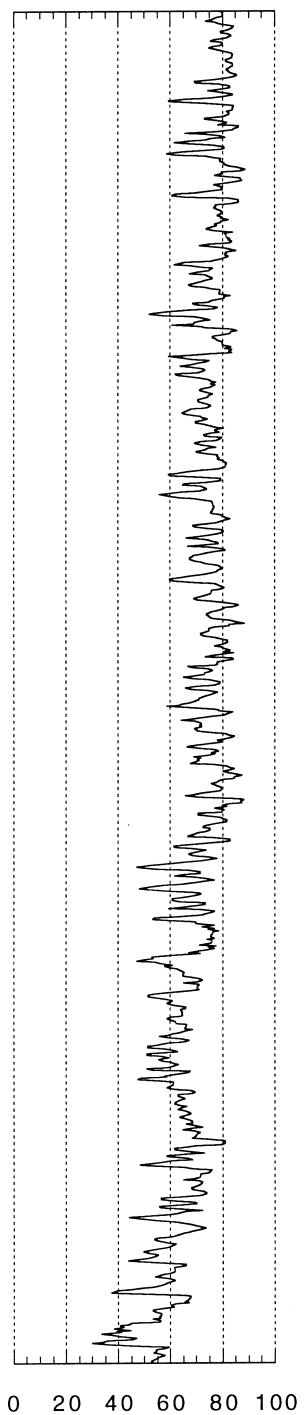

927

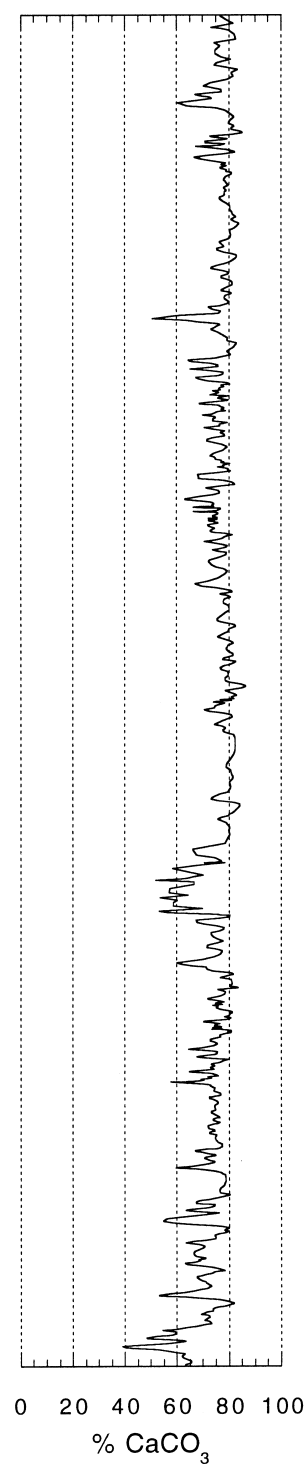

928

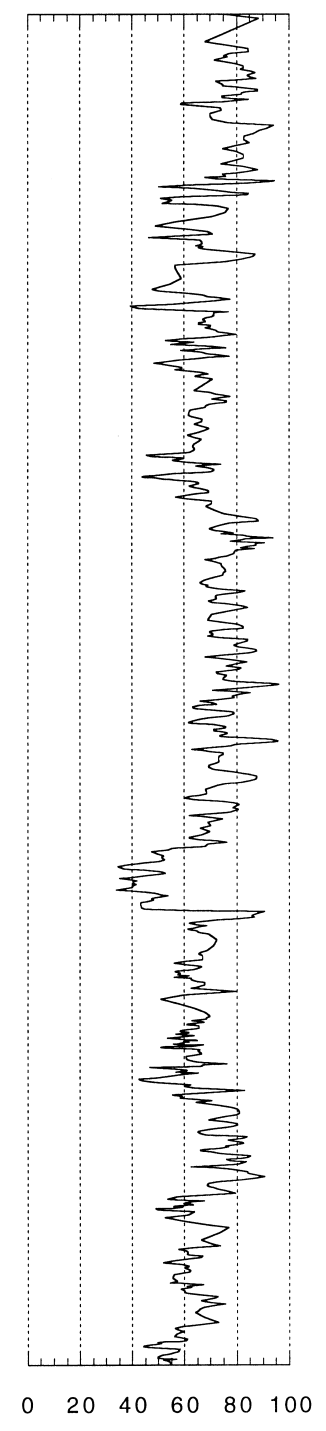

$\begin{array}{llllll}0 & 20 & 40 & 60 & 80 & 100\end{array}$

Figure 7 (continued). 
T.A. KING ET AL.
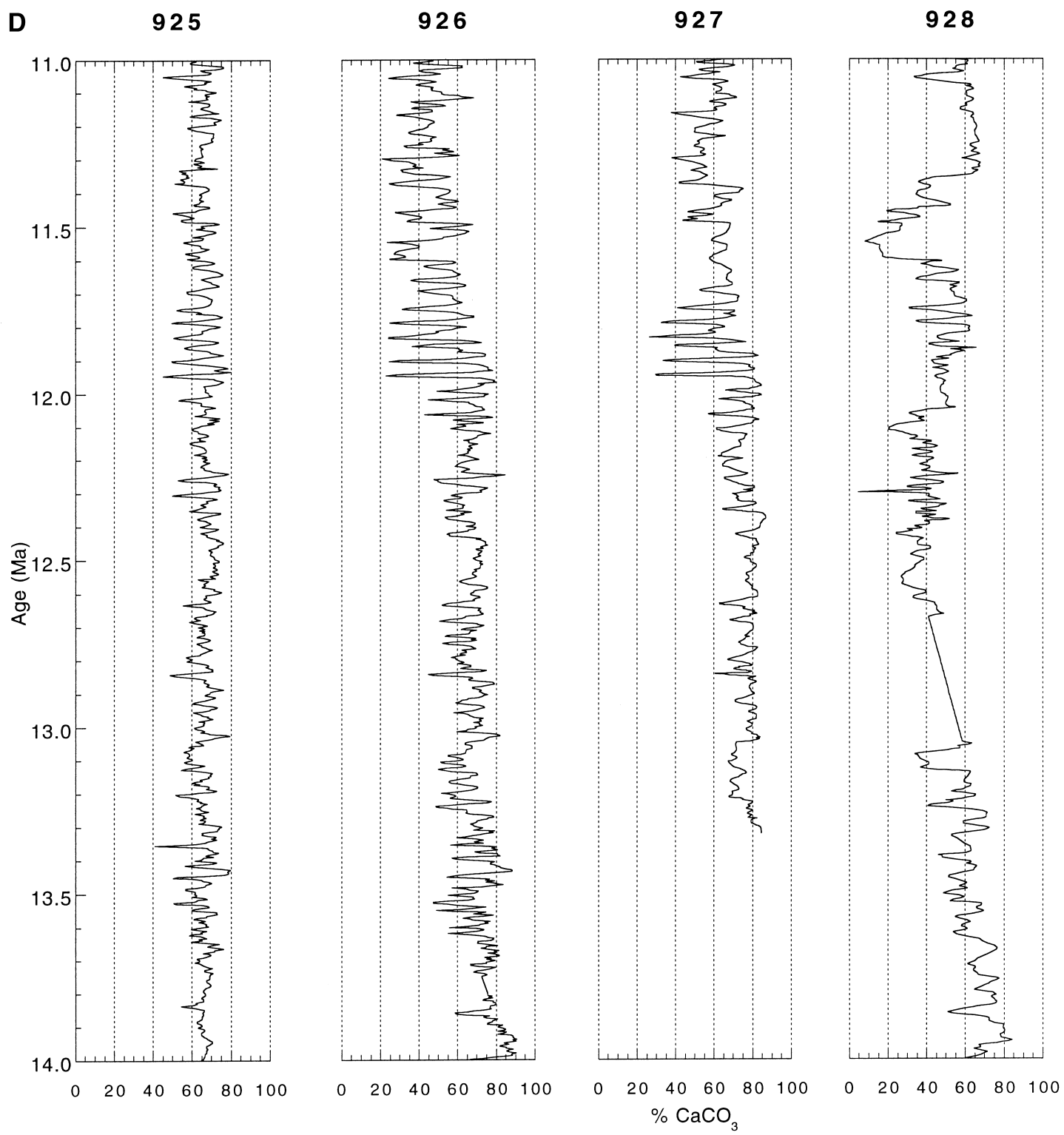

Figure 7 (continued). 


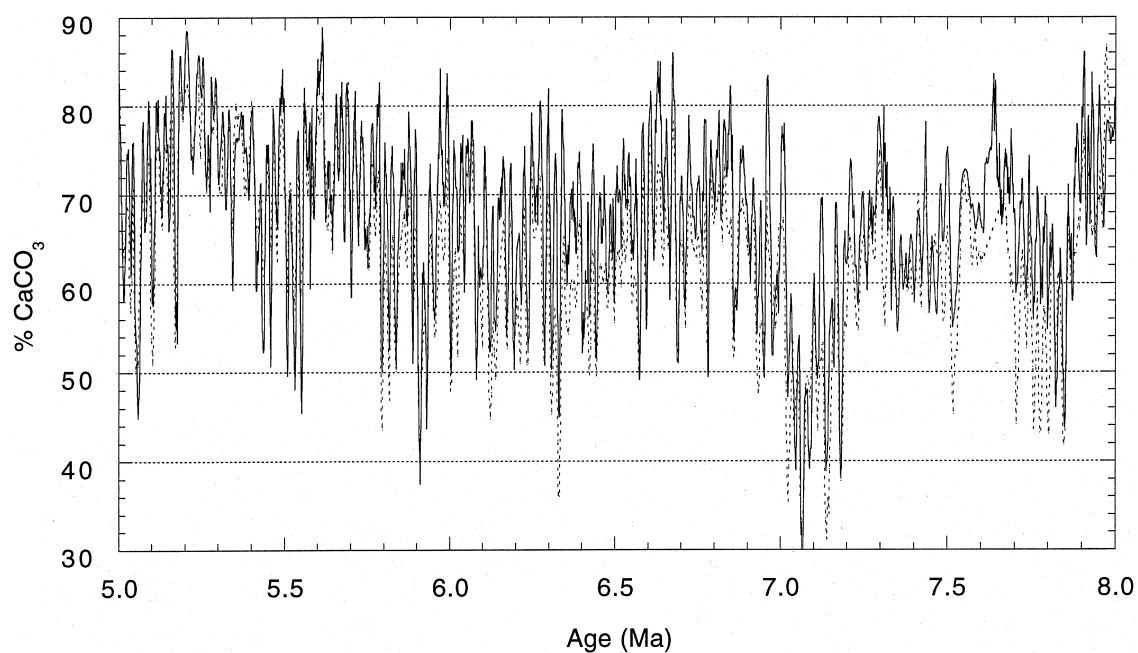

Figure 8. Comparison of predicted carbonate for a 3 m.y. interval of Site 926 to those of Shackleton and Crowhurst (this volume), derived from a different approach. Solid line = this study, dashed line $=$ Shackleton and Crowhurst (this volume).

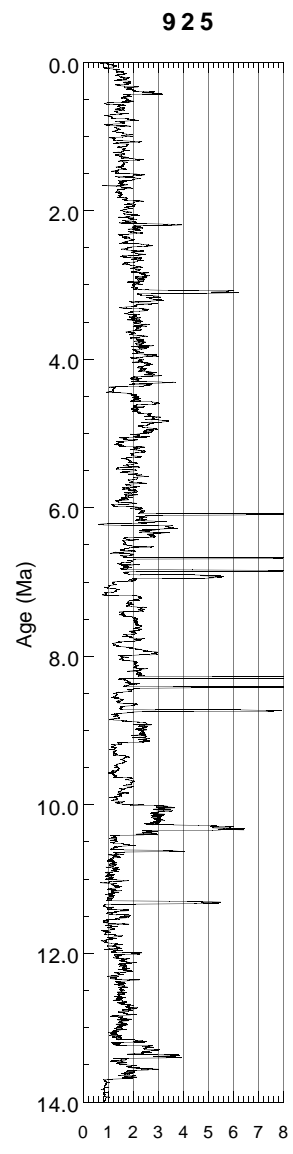

926

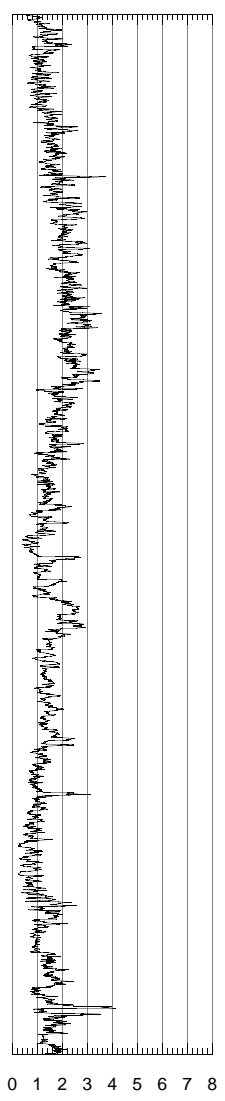

927

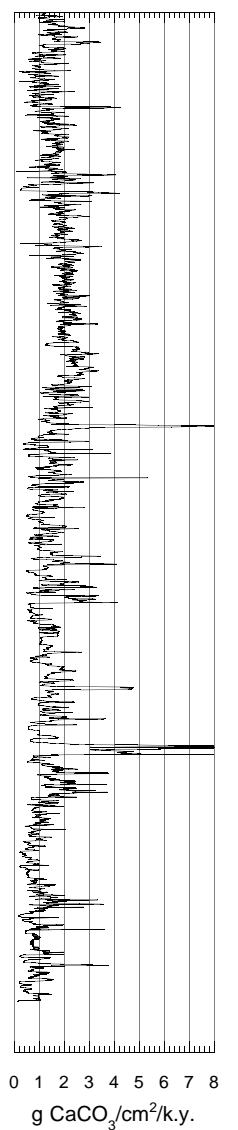

928

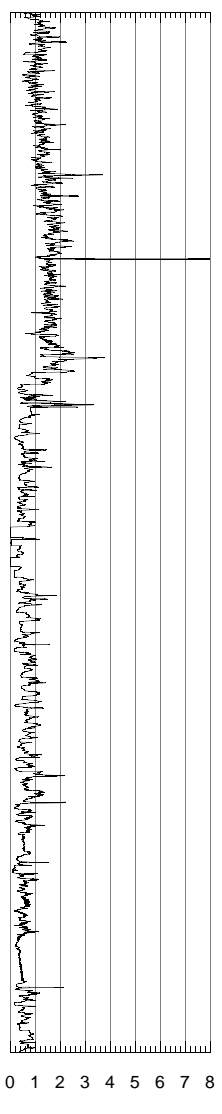

929

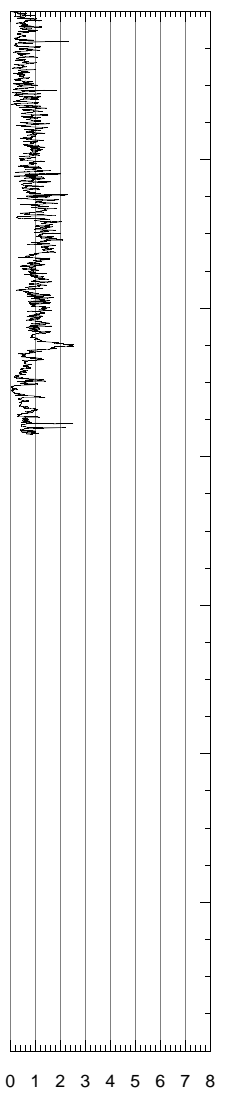

Figure 9. $\mathrm{CaCO}_{3}$ MAR estimates, Sites 925-929, 0-14 Ma. 
T.A. KING ET AL.
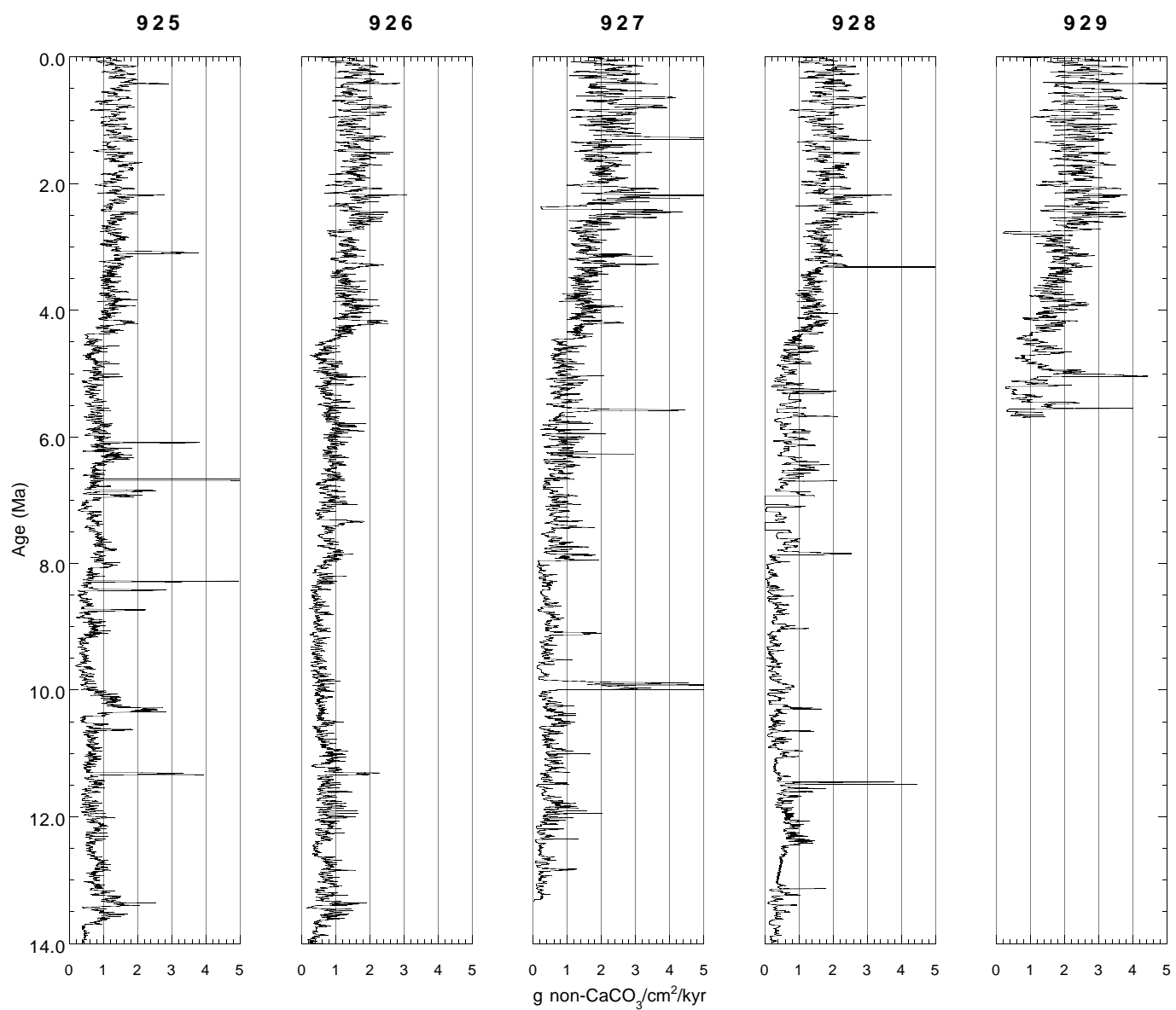

Figure 10. Non- $\mathrm{CaCO}_{3}$ MAR estimates, Sites 925-929, 0-14 Ma. 
Ceara Rise $\mathrm{CaCO}_{3}$ flux

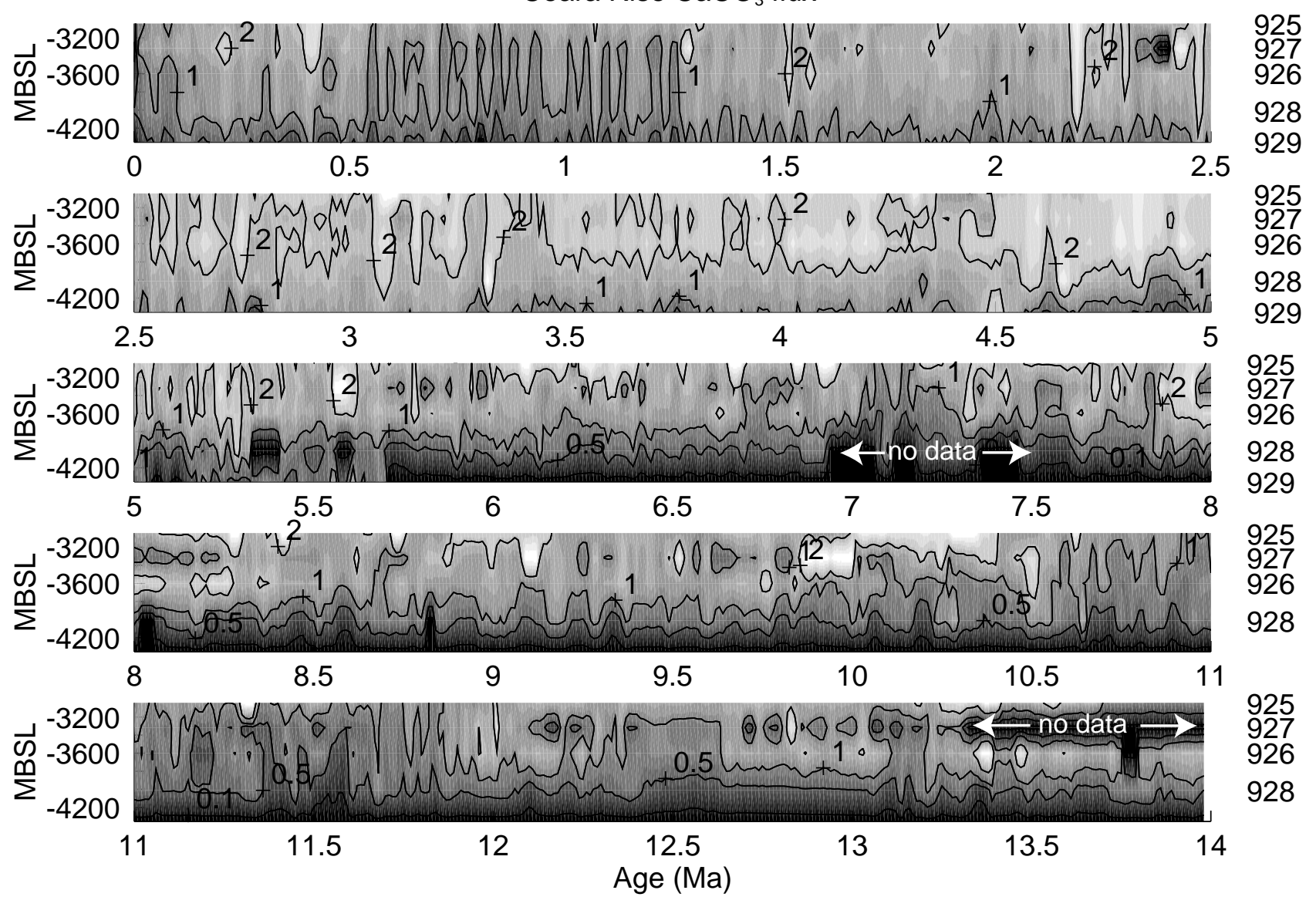

Figure 11. Carbonate MAR vs. time and depth, 0-14 Ma. Lighter colors indicate higher $\mathrm{CaCO}_{3}$ flux (white $=\geq 4.0 \mathrm{~g} \mathrm{CaCO} / \mathrm{cm}^{2} / \mathrm{k}$.y., black $=0 \mathrm{~g} \mathrm{CaCO} / \mathrm{cm}^{2} /$ k.y.). Contours are indicated at levels of $0.1,0.5$, and $2.0 \mathrm{~g} \mathrm{CaCO}_{3} / \mathrm{cm}^{2} / \mathrm{k} . \mathrm{y}$. 